ARTICLE

\title{
Cationic cluster formation versus disproportionation of low-valent indium and gallium complexes of 2,2'-bipyridine
}

Martin R. Lichtenthaler', Florian Stahl', Daniel Kratzert ${ }^{1}$, Lorenz Heidinger ${ }^{2}$, Erik Schleicher ${ }^{2}$, Julian Hamann ${ }^{1}$, Daniel Himmel ${ }^{1}$, Stefan Weber ${ }^{2}$ \& Ingo Krossing ${ }^{1}$

Group $13 M^{\prime}$ compounds often disproportionate into $M^{0}$ and $M^{\prime \prime \prime}$. Here, however, we show that the reaction of the $\mathrm{M}^{\prime}$ salt of the weakly coordinating alkoxyaluminate $\left[\mathrm{Ga}^{\mathrm{l}}\left(\mathrm{C}_{6} \mathrm{H}_{5} \mathrm{~F}\right)_{2}\right]^{+}\left[\mathrm{Al}\left(\mathrm{OR}^{\mathrm{F}}\right)_{4}\right]^{-}\left(\mathrm{R}^{\mathrm{F}}=\mathrm{C}\left(\mathrm{CF}_{3}\right)_{3}\right)$ with 2,2'-bipyridine (bipy) yields the paramagnetic and distorted octahedral $\left[\mathrm{Ga}(\mathrm{bipy})_{3}\right]^{2+}\left\{\left[\mathrm{Al}\left(\mathrm{OR}^{\mathrm{F}}\right)_{4}\right]^{-}\right\}_{2}$ complex salt. While the latter appears to be a Gall compound, both, EPR and DFT investigations assign a ligandcentred $\left.\left[\mathrm{Ga} \mathrm{III}^{\mathrm{I}}\{\text { (bipy })_{3}\right\}^{\bullet}\right]^{2+}$ radical dication. Surprisingly, the application of the heavier homologue $\left[\mathrm{n}^{\mathrm{l}}\left(\mathrm{C}_{6} \mathrm{H}_{5} \mathrm{~F}\right)_{2}\right]^{+}\left[\mathrm{Al}\left(\mathrm{OR}^{\mathrm{F}}\right)_{4}\right]^{-}$leads to aggregation and formation of the homonuclear cationic triangular and rhombic $\left[\ln _{3}(\text { bipy })_{6}\right]^{3+},\left[\ln _{3}(\text { bipy })_{5}\right]^{3+}$ and $\left[\ln _{4}(\text { bipy })_{6}\right]^{4+}$ metal atom clusters. Typically, such clusters are formed under strongly reductive conditions. Analysing the unexpected redox-neutral cationic cluster formation, DFT studies suggest a stepwise formation of the clusters, possibly via their triplet state and further investigations attribute the overall driving force of the reactions to the strong $\ln -\ln$ bonds and the high lattice enthalpies of the resultant ligand stabilized $\left[\mathrm{M}_{3}\right]^{3+}\left\{\left[\mathrm{Al}\left(\mathrm{OR}^{\mathrm{F}}\right)_{4}\right]^{-}\right\}_{3}$ and $\left[\mathrm{M}_{4}\right]^{4+}$ $\left\{\left[\mathrm{Al}\left(\mathrm{OR}^{\mathrm{F}}\right)_{4}\right]^{-}\right\}_{4}$ salts.

\footnotetext{
${ }^{1}$ Institut für Anorganische und Analytische Chemie and Freiburger Materialforschungszentrum (FMF), Albert-Ludwigs-Universität Freiburg, Albertstr. 21 and Stefan-Meier Str. 21, 79104 Freiburg, Germany. ${ }^{2}$ Institut für Physikalische Chemie and Freiburg Institute of Advanced Studies (FRIAS), Albert-LudwigsUniversität Freiburg, Albertstr. 21 and Albertstr. 19, 79104 Freiburg, Germany. Correspondence and requests for materials should be addressed to I.K. (email: krossing@uni-freiburg.de).
} 
n 1966, F. A. Cotton defined the term metal atom cluster compound as 'those containing a finite group of metal atoms which are held together entirely, mainly, or at least to a significant extent, by bonds directly between the metal atoms even though some non-metal atoms may be associated intimately

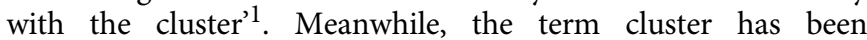
expanded, describing various ensembles of bonded atoms (both metal and non-metal) or molecules, thus including compounds such as the boranes and carboranes ${ }^{2,3}$, Zintl-like phases ${ }^{4}$, salt-like clusters $^{5}$ as well as metalloid clusters ${ }^{6}$. Among the many routes leading to metal atom cluster compounds, the reductive and anionic syntheses prevail: such clusters are typically electron deficient and have a strong demand for additional electrons that can be provided by reductants such as alkaline metals or through electron transfer reactions like disproportionations ${ }^{6,7}$. Alternatively, aggregation can be achieved by applying strong donor ligands: for example, the carbene-mediated formation of the neutral $\mathrm{P}_{12}$ non-metal cluster ${ }^{8}$. Though the different approaches have yielded a vast number of neutral and anionic cluster compounds, the redox-neutral synthesis of cationic clusters by low-valent cation aggregation has not been reported to our knowledge. Thus, univalent group 13 metal salts such aspartly hypothetic $-\mathrm{M}^{+} \mathrm{A}^{-}\left(\mathrm{M}=\mathrm{Al}, \mathrm{Ga}, \mathrm{In}, \mathrm{Tl} ; \mathrm{A}=\mathrm{Cl},\left[\mathrm{AsF}_{6}\right]\right.$, $\left[\mathrm{Al}\left(\mathrm{OR}^{\mathrm{F}}\right)_{4}\right]$ with $\left.\mathrm{R}^{\mathrm{F}}=\mathrm{C}\left(\mathrm{CF}_{3}\right)_{3}\right)$ could in principle aggregate, yielding the electron precise $\left[\mathrm{M}_{3}\right]^{3+}\left(\mathrm{A}^{-}\right)_{3}$ cluster salt (Fig. 1, right).

The simple $\mathrm{M}^{+} \mathrm{Cl}^{-}$salts however, are prone to disproportionate to elemental $\mathrm{M}^{0}$ and $\mathrm{M}^{3+}\left(\mathrm{Cl}^{-}\right)_{3}$, due to the high and favourable lattice energies of $\mathrm{MCl}_{3}$ (Fig. 1, left). Thus, $\mathrm{AlCl}$ is only known as a gas phase molecule ${ }^{9}$, and a hypothetic salt $\mathrm{Al}^{+} \mathrm{Cl}^{-}$ would disproportionate to elemental $\mathrm{Al}^{0}$ and $\mathrm{AlCl}_{3}$ (solid-state reaction enthalpy $\Delta_{\mathrm{r}} \mathrm{H}^{\circ}$ (solid) $=-396 \mathrm{~kJ} \mathrm{~mol}^{-1}$, cf. Born-HaberFajans Cycle (BHFC), Supplementary Fig. 9). For the heavier element indium on the other hand, the oxidation state +1 is more favourable due to inert pair effects ${ }^{10}$ and the known salt $\mathrm{In}^{+} \mathrm{Cl}^{-}$(refs 11,12) is stable towards disproportionation by $+31 \mathrm{~kJ} \mathrm{~mol}^{-1}$ (BHFC, Supplementary Fig. 9). Yet, the alternative formation of the metal atom cluster $\left[\mathrm{M}_{3}\right]^{3+}$ is hampered by the lower lattice energies of $\left[\mathrm{M}_{3}\right]^{3+}\left(\mathrm{A}^{-}\right)_{3}$ compared with $\mathrm{M}^{3+}\left(\mathrm{A}^{-}\right)_{3}$ and, most of all, the very distinct Coulomb repulsion (Fig. 1, right). Thus, a gaseous triangular $\left[\mathrm{M}_{3}\right]^{3+}$ cluster would Coulomb-explode, releasing $+1,544 \mathrm{~kJ} \mathrm{~mol}^{-1}$ Coulomb energy at a typical $\mathrm{M}-\mathrm{M}$ distance of $270 \mathrm{pm}$. The cluster formation, however, becomes favoured for larger anions $\mathrm{A}^{-}$: that is, the difference of the estimated lattice enthalpies $\left(\Delta_{\text {latt }} H^{\circ}\right)$ of the $\mathrm{In}^{3+}\left(\mathrm{A}^{-}\right)_{3}$ and $\left[\mathrm{In}_{3}\right]^{3+}\left(\mathrm{A}^{-}\right)_{3}$ salts is $+697 \mathrm{~kJ} \mathrm{~mol}^{-1}$ for $\mathrm{Cl}^{-}$ $\left(V^{-}=0.047 \mathrm{~nm}^{3}\right),+281 \mathrm{~kJ} \mathrm{~mol}^{-1}$ for $\left[\mathrm{AsF}_{6}\right]^{-}\left(V^{-}=0.110 \mathrm{~nm}^{3}\right)$ but only $+26 \mathrm{~kJ} \mathrm{~mol}^{-1}$ for $\left[\mathrm{Al}\left(\mathrm{OR}^{\mathrm{F}}\right)_{4}\right]^{-} \quad\left(V^{-}=0.758 \mathrm{~nm}^{3}\right.$; Supplementary Tables 10 and 11). Overall, salts with very large anions like $\left[\mathrm{Al}\left(\mathrm{OR}^{\mathrm{F}}\right)_{4}\right]^{-}$and ligands, allowing for a delocalization and thus 'dilution' of the positive charge on $\left[\mathrm{M}_{3}\right]^{3+}$, may support cationic cluster formation. Yet, the

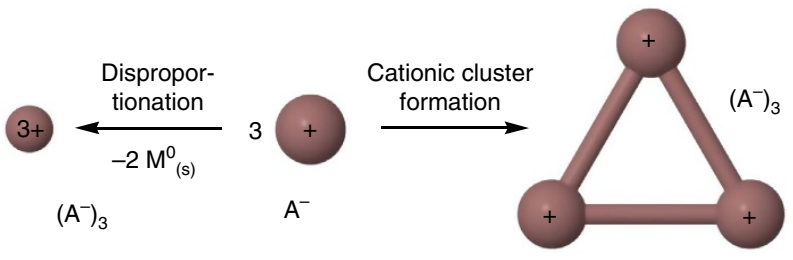

Figure 1 | Disproportionation versus cationic cluster formation of univalent group $\mathbf{1 3}$ metal salts $\mathbf{M}^{+} \mathbf{A}^{-}$. Generally, the disproportionation is favoured over the cluster formation due to the much higher lattice energies of the $\mathrm{M}^{3+}\left(\mathrm{A}^{-}\right)_{3}$ salt. question remains: what are suitable $\mathrm{Ga} / \mathrm{In}^{\mathrm{I}}$ sources to perform such a chemistry?

Stabilizing gallium in its low oxidation states $(<$ III $)$ has been an objective since the 1,930 s. (ref. 13) Subvalent gallium halides $\mathrm{Ga}^{\mathrm{I}}\left[\mathrm{Ga}^{\mathrm{III}} \mathrm{X}_{4}\right] \quad(\mathrm{X}=\mathrm{Cl}, \mathrm{Br} \text { and } \mathrm{I})^{14}$, 'GaI' (refs 15,16) and metastable, donor stabilized $\mathrm{Ga}^{\mathrm{I}} \mathrm{Cl}$ solutions ${ }^{9}$ are important milestones and to this day used as starting material for further $\mathrm{Ga}^{\mathrm{I}}$ chemistry: for example, arene- ${ }^{17}, \mathrm{Cp}^{\mathrm{x}}$-complexes $\left(\mathrm{Cp}^{\mathrm{x}}\right.$ : $\mathrm{Cp}=\mathrm{C}_{5} \mathrm{H}_{5}$ and $\mathrm{Cp}^{\star}=\mathrm{C}_{5} \mathrm{Me}_{5}$ ), (ref. 18) N-heterocyclic carbene (NHC) analogues ${ }^{19,20}$ of $\mathrm{Ga}^{\mathrm{I}}$, or metalloidal gallium clusters ${ }^{7}$. In addition, the neutral $\mathrm{Ga}^{\mathrm{I}}-\mathrm{Cp} / \mathrm{Cp}^{\star}$ complexes as well as the gallaNHC analogues have been applied as ligands for transitionmetals ${ }^{21}$. Due to the strongly coordinating halide anions, however, $\mathrm{Ga}^{\mathrm{I}}\left[\mathrm{Ga}^{\mathrm{III}} \mathrm{X}_{4}\right]$ and 'GaI' are prone to com- and disproportionation reactions ${ }^{15,17}$. Donor-free $\mathrm{Ga}^{\mathrm{I}} \mathrm{Cl}$ and related compounds are only accessible at very low temperatures using elaborated matrix isolation techniques ${ }^{9}$. Simple indium halides In $^{\mathrm{I}} \mathrm{X}(\mathrm{X}=\mathrm{Cl}, \mathrm{Br} \text { and } \mathrm{I})^{11,12,22}$ are stable at ambient conditions (vide supra). In contrast to the $\mathrm{Ga}^{\mathrm{I}}$ systems, the halide anions can be replaced for weakly coordinating anions (WCAs) of different sizes including $\left[\mathrm{BF}_{4}\right]^{-}$(ref. 23), $[\mathrm{OTf}]^{-}\left(\mathrm{Tf}=\mathrm{SO}_{2} \mathrm{CF}_{3}\right)^{24}$, $\left[\mathrm{PnF}_{6}\right]^{-}(\mathrm{Pn}=\mathrm{P}, \mathrm{As}, \mathrm{Sb})^{25}$ and $\left[\mathrm{Al}\left(\mathrm{OR}^{\mathrm{F}}\right)_{4}\right]^{-}\left(\mathrm{R}^{\mathrm{F}}=\mathrm{C}\left(\mathrm{CF}_{3}\right)_{3}\right)^{26}$. Various In ${ }^{\mathrm{I}}-\mathrm{Cp}$ complexes ${ }^{22}$ have also been used as catalysts in organic syntheses 27 . Our group introduced a simple route to univalent gallium and indium salts of the weakly coordinating $\left[\mathrm{Al}\left(\mathrm{OR}^{\mathrm{F}}\right)_{4}\right]^{-}$anion, by oxidizing elemental gallium and indium with $\mathrm{Ag}^{+}\left[\mathrm{Al}\left(\mathrm{OR}^{\mathrm{F}}\right)_{4}\right]^{-}$in fluorobenzene $\left(\mathrm{C}_{6} \mathrm{H}_{5} \mathrm{~F}\right)^{28,29}$. Under inert conditions, the $\left[\mathrm{M}\left(\mathrm{C}_{6} \mathrm{H}_{5} \mathrm{~F}\right)_{2}\right]^{+}\left[\mathrm{Al}\left(\mathrm{OR}^{\mathrm{F}}\right)_{4}\right]^{-}$salts $(\mathrm{M}=\mathrm{Ga}$ (1), In (2)) are stable, soluble in aromatic solvents (preferably fluorinated), and a potent starting material for further $\mathrm{Ga}^{\mathrm{I}}$ and $\operatorname{In}^{\mathrm{I}}$ chemistry: for example, phosphine ${ }^{29}$, crown ether ${ }^{30}$, carbene $^{31}$ and $\mathrm{N}$-heterocyclic arene ${ }^{32}$ complexes. In addition, the $\left[\mathrm{Ga}(\text { arene })_{1-2}\right]^{+}$complexes (arene $=\mathrm{C}_{6} \mathrm{H}_{5} \mathrm{~F}$, mesitylene, diphenylethane, $m$-terphenyl) are highly efficient isobutylene polymerization catalysts ${ }^{33,34}$.

Herein we report on the surprising reactions of $\left[\mathrm{M}\left(\mathrm{C}_{6} \mathrm{H}_{5} \mathrm{~F}\right)_{2}\right]^{+}\left[\mathrm{Al}\left(\mathrm{OR}^{\mathrm{F}}\right)_{4}\right]^{-}$salts mainly with 2,2'-bipyridine (bipy), but also with the bipy-relative 1,10-phenanthroline (phen).

\section{Results}

Orienting quantum-chemical calculations. In contrast to the anionic chelating $\mathrm{N}$-ligands for univalent gallium and indium, for example, guanidinates ${ }^{35}$, diazabutadienes ${ }^{19,20,36}$, $\beta$-diketiminates ${ }^{20,37}$ or tris(pyrazolyl)hydroborates $(\mathrm{Tp})^{38}$, neutral N-ligands, like pyridine derivatives, were shown to only stabilize the +1 oxidation state of indium ${ }^{39}$, but not of gallium ${ }^{40,41}$. Applying $\left[\mathrm{Ga}^{\mathrm{I}}\left(\mathrm{C}_{6} \mathrm{H}_{5} \mathrm{~F}\right)_{2}\right]^{+}\left[\mathrm{Al}\left(\mathrm{OR}^{\mathrm{F}}\right)_{4}\right]^{-}$(1), however, we were able to isolate the first gallium(I) complexes with simple N-ligands, such as pyrazine and di-tertbutylmethylpyridine ${ }^{32}$. To expand the scope to neutral chelating $\mathrm{N}$-ligands, we investigated the thermodynamics of potential ligand exchange reactions of the $\left[\mathrm{M}\left(\mathrm{C}_{6} \mathrm{H}_{5} \mathrm{~F}\right)_{2}\right]^{+}$complexes $(\mathrm{M}=\mathrm{Ga}$, In) and 1 to 3 equivalents bipy. All turned out to be exothermic/exergonic by at least $-146 \mathrm{~kJ} \mathrm{~mol}^{-1}$ (Supplementary Table 9). Thus, it appeared interesting to test the reactions.

Reaction of $\left[\mathrm{Ga}^{\mathrm{I}}\left(\mathrm{C}_{6} \mathrm{H}_{5} \mathrm{~F}\right)_{2}\right]^{+}\left[\mathrm{Al}\left(\mathrm{OR}^{\mathrm{F}}\right)_{4}\right]^{-}$with bipy. On mixing colourless solutions of $\mathbf{1}$ and bipy (2.00 eq) in ortho-difluorobenzene $\left(o-\mathrm{C}_{6} \mathrm{H}_{4} \mathrm{~F}_{2}\right)$, an unexpected distinct change in colour towards moss-green was observed (Supplementary Data 1-7). To promote crystallization, the reaction mixture was concentrated by slowly removing the volatiles under reduced pressure. During this process, the formation of a black precipitate was observed, while the colour of the solution remained green. Applying $\mathrm{C}_{6} \mathrm{H}_{5} \mathrm{~F}$ as 
solvent, similar observations were made, though the precipitate formed without concentrating the solution. From the $o-\mathrm{C}_{6} \mathrm{H}_{4} \mathrm{~F}_{2}$ solutions, green platelet single crystals were repeatedly isolated and surprisingly characterized as $\left[\mathrm{Ga}(\text { bipy })_{3}\right]^{2+}\left\{\left[\mathrm{Al}\left(\mathrm{OR}^{\mathrm{F}}\right)_{4}\right]^{-}\right\}_{2}$ (3) and not as the predicted $\left[\mathrm{Ga}(\text { bipy })_{2}\right]^{+}$complex (cf. Supplementary Table 9). Though the $\left[\mathrm{Al}\left(\mathrm{OR}^{\mathrm{F}}\right)_{4}\right]^{-}$anions are crucial in terms of stabilizing the low-valent oxidation states of gallium and indium, all structures within this manuscript feature no $\mathrm{Ga}-\mathrm{F}$ or In $-\mathrm{F}$ contact shorter than the sum of the corresponding van der Waals radii ${ }^{42,43}$. The structural discussions are therefore focused on the obtained cationic complexes and clusters. To our knowledge, the dicationic, paramagnetic and distorted octahedral $\left[\mathrm{Ga}(\text { bipy })_{3}\right]^{2+}$ complex $\left(3^{2+}\right)$ is the first structurally characterized one of its kind, thus differing from the $\left[\mathrm{Ga} \text { (bipy) }{ }_{3}\right]^{3+}$ complex obtained, if ' $\mathrm{GaI}$ ' is applied as gallium(I) starting material (Fig. 2) ${ }^{40}$. The synthesis of $3^{2+}$ is the first example, where $\mathbf{1}$ did not act as a pure $\mathrm{Ga}^{\mathrm{I}}$ source but disproportionated (vide infra). With a total charge of $2+$, it is tempting to proclaim the successful stabilization of a monomeric, room-temperature stable $\mathrm{Ga}^{\mathrm{II}}$ species, that is, a $\left[\left(\mathrm{Ga}^{\mathrm{II}}\right)^{\bullet}(\text { bipy })_{3}\right]^{2+}$ complex.

While earlier reported $\mathrm{Ga}^{\mathrm{II}}$ compounds have proven to be mixed-valent species ${ }^{14}$ or diamagnetic dimers ${ }^{44}$, Aldridge et al. recently reported on a thermally robust monomeric $\mathrm{Ga}^{\mathrm{II}}$ compound: $\left[\mathrm{Ga}^{\mathrm{II}}\left\{\mathrm{B}\left(\mathrm{N}\left(\mathrm{C}_{6} \mathrm{H}_{3}-2,3-i \mathrm{Pr}\right) \mathrm{CH}\right)_{2}\right\}_{2}\right]^{45}$. In this $\mathrm{Ga}^{\mathrm{II}}$ molecule, the metal atom is coordinated in a bent fashion by
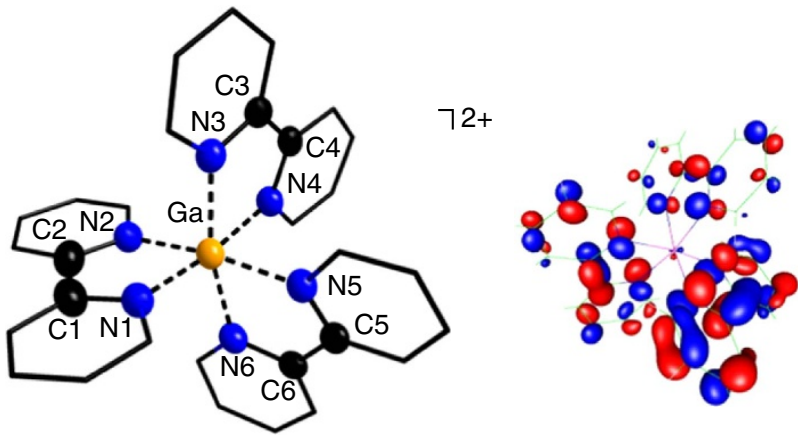

Figure 2 | Molecular structure of $\left[\mathbf{G a}(\mathbf{b i p y})_{3}\right]^{\mathbf{2}+} \cdot\left(\mathbf{3}^{\mathbf{2}+}\right)$. Selected bond lengths are given in pm: $\mathrm{Ga}-\mathrm{N} 1=202.6(4), \mathrm{Ga}-\mathrm{N} 2=202.6(4)$, $\mathrm{Ga}-\mathrm{N} 3=205.8(4), \mathrm{Ga}-\mathrm{N} 4=208.2(4), \mathrm{Ga}-\mathrm{N} 5=208.2(4)$, $\mathrm{Ga}-\mathrm{N} 6=205.8(4), \mathrm{C} 1-\mathrm{C} 2=149.2(12)$ and $\mathrm{C} 3-\mathrm{C} 4=148.6(7)$, $\mathrm{C} 5-\mathrm{C} 6=148.6(7)$. The earlier reported $\left[\mathrm{Ga}(\text { bipy })_{3}\right]^{3+}$ complex features a slightly longer average $\mathrm{Ga}-\mathrm{N}$ bond length of $206.4 \mathrm{pm}$ (cf. 205.5(4) pm for $\mathbf{3}^{\mathbf{2}}$ ) and a slightly shorter average $\mathrm{C}_{1,3,5}-\mathrm{C}_{2,4,6}$ bond length of 147.9 pm (cf. 148.8(9) pm for $\left.\mathbf{3}^{\mathbf{2}+}\right)^{40}$. The $\left[\mathrm{Al}\left(\mathrm{ORF}^{\mathrm{F}}\right)_{4}\right]^{-}$anions and all of the hydrogen atoms were omitted for clarity. The thermal ellipsoids are set at $50 \%$ probability. An alternative presentation, featuring ellipsoids for all atoms, is included in Supplementary Fig. 6. As an inset, the figure also includes the B3LYP/SV (P) level frontier and singly occupied Kohn-Sham orbital (SOMO) of $\mathbf{3}^{\mathbf{2}+}$, electron density cutoff at 0.04 a.u. The calculated distances of the latter are in good agreement with the experimental results (bond lengths in pm, similar label scheme): $\mathrm{Ga}-\mathrm{N} 1=206.4$,

$\mathrm{Ga}-\mathrm{N} 2=206.8, \mathrm{Ga}-\mathrm{N} 3=211.6, \mathrm{Ga}-\mathrm{N} 4=213.2, \mathrm{Ga}-\mathrm{N} 5=211.1$, $\mathrm{Ga}-\mathrm{N} 6=209.1, \mathrm{C} 1-\mathrm{C} 2=145.7, \mathrm{C} 3-\mathrm{C} 4=147.7$ and C5 $-\mathrm{C} 6=146.9$. Yet, and more importantly, the SOMO is primarily located on the bipy ligands, thus speaking for a $\left[\mathrm{Ga} \mathrm{a}^{\mathrm{III}}\left\{(\mathrm{bipy})_{3}\right\}^{\bullet}\right]^{2+}$ rather than a $\left.\left[\left(\mathrm{Ga}^{\mathrm{Il}}\right)^{\bullet} \text { (bipy) }\right]_{3}\right]^{2+}$ complex. Applying the BHLYP/SV(P) level of theory, the SOMO is solely located on one bipy ligand, corresponding to a

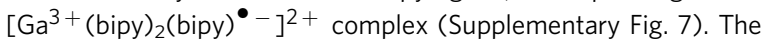
calculated distances of the latter are in inferior agreement with the experimental results and therefore $\mathbf{3}^{\mathbf{2}}$ more likely corresponds to the $\left.\left[\mathrm{Ga} \mathrm{a}^{\mathrm{III}}\{\text { (bipy) }\}_{3}\right\}^{\bullet}\right]^{2+}$ formulation. two boryl ligands and over $70 \%$ of the unpaired spin density is located on the metal. The related $\left[\mathrm{Ga}(\mathrm{dabab})_{2}\right]$ complex $^{46}$ (dabab $=1,4$-di-tert-butyl-1,4-diazabutadiene) on the other hand, is correctly described as a $\mathrm{Ga}^{\mathrm{III}}$ cation coordinated by one singly and one doubly reduced dabab ligand ${ }^{36,47-50}$. A related description could account for $\mathbf{3}^{\mathbf{2}+}$, that is, a $\left[\mathrm{Ga}^{\mathrm{III}}\left\{(\text { bipy })_{3}\right\}^{\bullet}\right]^{2+}$ complex, and therefore we conducted electron paramagnetic resonance (EPR) spectroscopy measurements of solutions of $\mathbf{3}$ in $o-\mathrm{C}_{6} \mathrm{H}_{4} \mathrm{~F}_{2}$ (Fig. 3). Both, the isotropic $g$-value $\left(g_{\text {iso }}=2.0024\right)$ being close to that of the free electron and the low $g$ anisotropy ${ }^{[7 a]}$ speak in favour of a ligand-centred spin system. This assumption is further supported by the low hyperfine coupling constant $A\left({ }^{69} \mathrm{Ga}\right)=21 \mathrm{MHz}$, thus being in good agreement with studies by Kaim et $a l .{ }^{47}$ and clearly differing from the above mentioned metal-centred spin system $\left[\mathrm{Ga}^{\mathrm{II}}\left\{\mathrm{B}\left(\mathrm{N}\left(\mathrm{C}_{6} \mathrm{H}_{3}-2,3-i \mathrm{Pr}\right) \mathrm{CH}\right)_{2}\right\}_{2}\right]$ (cf. $\left.A\left({ }^{69} \mathrm{Ga}\right)=670 \mathrm{MHz}\right){ }^{45}$.

Furthermore, we applied density functional theory (DFT) calculations to compute the singly occupied molecular orbitals (Fig. 2, inset) and the spin density of $\mathbf{3}^{\mathbf{2}}$ (Fig. 3, inset). We chose

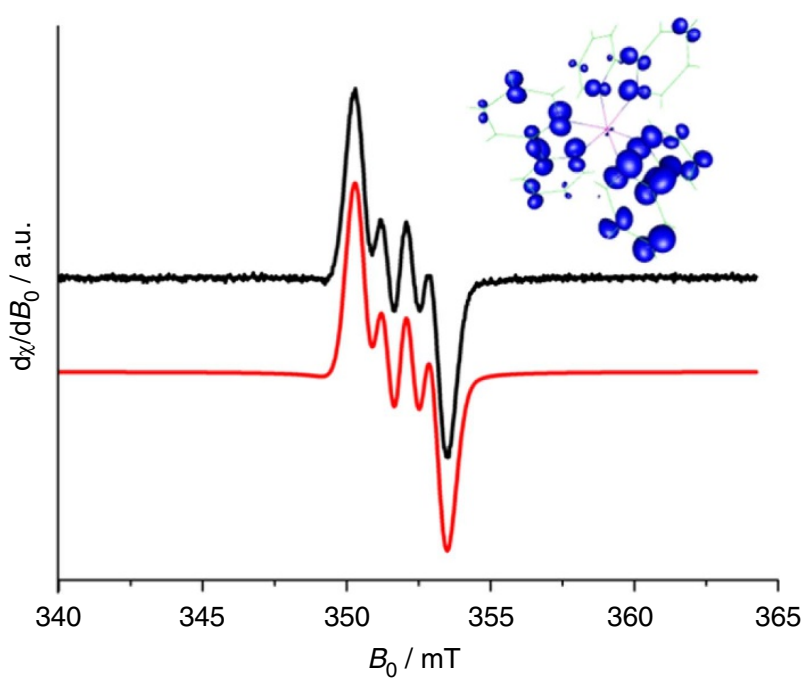

Figure 3 | EPR investigations of $\left[\mathrm{Ga}(\text { bipy })_{3}\right]^{\mathbf{2}+}{ }^{\bullet}\left[\mathrm{AAI}\left(\mathrm{OR}^{\mathrm{F}}\right)_{\mathbf{4}}\right]^{-} \boldsymbol{\}}_{\mathbf{2}}$ (3). $X$-band continuous wave EPR spectrum of a solution of $\mathbf{3}$ in $0-\mathrm{C}_{6} \mathrm{H}_{4} \mathrm{~F}_{2}$ $(1 \mathrm{mM})$ (black trace; recorded at room temperature, microwave frequency $9.861 \mathrm{GHz}$, magnetic-field modulation amplitude $0.1 \mathrm{mT}$, microwave power $2 \mathrm{~mW}$ ) and the corresponding spectral simulation (red trace). The measurement and its spectral simulation exhibit an isotropic gallium dominated resonance with a $g$-value $\left(g_{\text {iso }}\right)$ of 2.0024 and a hyperfine coupling constant of $A\left({ }^{69} \mathrm{Ga}\right)=21 \mathrm{MHz}$, thus supporting an isotropic spin density of $<1.0 \%$ on the gallium atom and a ligand-centred spin system, while the exact whereabouts of the radical in the ligand backbone could not be identified. The $A\left({ }^{69} \mathrm{Ga}\right)$ value strongly deviates from the theoretical hyperfine coupling constant of an isolated ${ }^{69} \mathrm{Ga}$ atom

$\left(A\left({ }^{69} \mathrm{Ga}\right)=12210 \mathrm{MHz}\right)^{68,69}$. In addition spectra were obtained from frozen solutions of $\mathbf{3}$ in $\mathrm{C}_{6} \mathrm{H}_{5} \mathrm{~F}$ or $0-\mathrm{C}_{6} \mathrm{H}_{4} \mathrm{~F}_{2}$ and both show a weak $g$ anisotropy (Supplementary Fig. 4). As an inset, the figure also includes the DFT calculated spin density of $\mathbf{3}^{\mathbf{2}+}$ (cutoff at 0.003 a.u., B3LYP/SV(P) level). With a distribution of $3.0 \%$ on the gallium atom and $97 \%$ on the bipy ligands, the latter corresponds to a $\left.\left[\mathrm{Ga}^{\mathrm{III}}\{\text { (bipy })_{3}\right\}^{\bullet}\right]^{2+}$ complex, thus being in very good agreement with the EPR results. An alternative modelling at the BHLYP/SV(P) level yielded a spin density distribution of $1.3 \%$ on the gallium atom and $98 \%$ on one bipy ligand (Supplementary Fig. 7), suggesting a formulation as $\left.\left[\mathrm{Ga}^{3+}(\text { bipy })_{2} \text { (bipy) }\right)^{\bullet-}\right]^{2+}$. Yet, a distribution of the spin density on all three ligands seems to be more likely as the calculated $\mathrm{C}-\mathrm{C}$ and $\mathrm{In}-\mathrm{N}$ bond lengths of the $\left.\left.\left[\mathrm{Ga} \mathrm{III}_{\{(\text {bipy }}\right)_{3}\right\}^{\bullet}\right]^{2+}$ complex are in much better agreement with the experimental results. 
the hybrid B3LYP/SV(P) method, as it yielded good agreements between calculated and experimental bond lengths of $3^{2+}$ (Fig. 2$)$, and the main absorption maximum $\left(\lambda_{\max }\right)$ in measured $(302 \mathrm{~nm})$ and simulated $(296 \mathrm{~nm})$ ultraviolet-visible spectra (Supplementary Fig. 5). These bands are reminiscent of the absorption of the related $\left.\left[\mathrm{Ru}^{3+}(\text { bipy })_{2}(\text { bipy })^{\bullet-}\right)\right]^{2+}$ complex $^{51}$ (cf. $\lambda_{\max }=373 \mathrm{~nm}$ ). Beyond featuring a similarly distorted octahedral coordination mode as its single-crystal congener, the singly occupied molecular orbitals of the geometry-optimized $3^{2}$ is solely located on the bipy ligands (Fig. 2) and only $3.0 \%$ of the spin is located at the gallium cation (Fig. 3). Overall, the experimental results (X-ray powder diffraction, EPR and ultraviolet-visible) and the DFT studies are in very good agreement and clearly assign a $\left[\mathrm{Ga}^{\mathrm{III}}\left\{(\text { bipy })_{3}\right\}^{\bullet}\right]^{2+}$ complex as correct formulation of $\mathbf{3}^{2+}$. To our knowledge, 3 is the first reported single-crystal structure of a p-block metal complex, featuring a bipy radical anion as ligand (cf. the few examples of alkali-metal salts of bipy radicals and dianions of Goicoechea et al. as well as Wieghardt's extensive work on transition-metal complexes of bipy $)^{52,53}$.

Reaction of $\left[\operatorname{In}^{\mathrm{I}}\left(\mathrm{C}_{6} \mathrm{H}_{5} \mathrm{~F}\right)_{2}\right]^{+}\left[\mathrm{Al}\left(\mathrm{OR}^{\mathrm{F}}\right)_{4}\right]^{-}$with bipy. Due to the redox instability of $\mathbf{1}$, we additionally reacted the heavier, more redox-stable homologue $\left[\operatorname{In}^{\mathrm{I}}\left(\mathrm{C}_{6} \mathrm{H}_{5} \mathrm{~F}\right)_{2}\right]^{+}\left[\mathrm{Al}\left(\mathrm{OR}^{\mathrm{F}}\right)_{4}\right]^{-}$(2) with bipy. While the isolation of single crystals from highly concentrated, yellowish solutions of 2 and bipy (2.00 eq or $1.63 \mathrm{eq}$ ) in $\mathrm{C}_{6} \mathrm{H}_{5} \mathrm{~F}$ was straightforward, the composition of the obtained crystals depended on the amount of bipy employed as well as the crystallization procedure. Overall, we were surprised not to isolate any of the predicted $\left[\operatorname{In}(\text { bipy })_{1-3}\right]^{+}$complexes (cf. Supplementary Table 9), but the very first homonuclear cationic triangular or rhombic $\operatorname{In}^{\mathrm{I}}$ clusters: $\left[\operatorname{In}_{3}^{\mathrm{I}}(\text { bipy })_{6}\right]^{3+}\left\{\left[\mathrm{Al}\left(\mathrm{OR}^{\mathrm{F}}\right)_{4}\right]^{-}\right\}_{3}$ (4), $\left[\operatorname{In}_{3}{ }_{3}(\text { bipy })_{5}\right]^{3+}\left\{\left[\mathrm{Al}\left(\mathrm{OR}^{\mathrm{F}}\right)_{4}\right]^{-}\right\}_{3} \quad(5)$ and $\left[\operatorname{In}_{4}{ }_{4}(\mathrm{bipy})_{6}\right]^{4+}$ $\left\{\left[\mathrm{Al}\left(\mathrm{OR}^{\mathrm{F}}\right)_{4}\right]^{-}\right\}_{4}(6)$. As above, the direct interaction between the cationic clusters and the $\left[\mathrm{Al}\left(\mathrm{OR}^{\mathrm{F}}\right)_{4}\right]^{-}$anions is negligible and the latter are therefore not shown in Fig. 4 . For the synthesis of $\mathbf{4}$, 2.04 equivalents of bipy were applied. In $4^{3+}$, each $\operatorname{In}^{\mathrm{I}}$ cation is coordinated in a distorted octahedral fashion, or in other words, three tetragonal pyramidal $\mathrm{N}$-coordinated $\left[\operatorname{In}^{\mathrm{I}}(\text { bipy })_{2}\right]^{+}$fragments interact with each other, thus forming the observed triangular cationic $\operatorname{In}^{\mathrm{I}}$ cluster. While the $\operatorname{In} 1-\operatorname{In} 2$ and $\operatorname{In} 1-\operatorname{In} 3$ bond lengths are very similar (266.07(4) and 266.98(5) pm, respectively), the In $2-\operatorname{In} 3$ distance is elongated by $11-12 \mathrm{pm}$. All three distances are well within the sum of the van der Waals radii ${ }^{42,43}$ $(386 \mathrm{pm})$ and among the shortest compared to the manifold of reported organometallic and inorganic compounds that feature In - In bonds (Table 1 and Supplementary Table 15).

Reducing the amount of bipy from 2.00 to 1.63 equivalents, we obtained compound 5. Though the molecular structure of $5^{3+}$ resembles the one of $4^{3+}$, one bipy ligand now acts as bridging $\mathrm{N}$-ligand between two $\mathrm{In}^{\mathrm{I}}$ cations, thus resulting in a more twisted arrangement of the two pyridine rings. These findings are likely attributable to the reduced amount of bipy employed and correspond well with the stoichiometry of the reaction (cf. '(5 bipy ligands $) /\left(3 \operatorname{In}^{\mathrm{I}}\right.$ cations $\left.) \approx 1.67^{\prime}\right)$. Hence, only $\operatorname{In} 2$ is coordinated in a distorted octahedral fashion, while In1 and In3 are coordinated in distorted trigonal bipyramidal fashions. The very short In - In bond lengths (Table 1) are similar within $3 \mathrm{pm}$ (av. In - In distance of 268.18(5) pm), thus resulting in an almost equilateral triangle. For 6, 2.00 equivalents of bipy were applied. Yet, and different to the synthesis of $\mathbf{4}$, the reaction mixture was additionally concentrated under reduced pressure, leading to the cationic, planar $\operatorname{In}^{\mathrm{I}}$ rhomb $\mathbf{6}^{\mathbf{4}}$. While the coordination modes of In 2 and In 4 resemble the ones of the $\operatorname{In}^{\mathrm{I}}$ cations in $4^{3+}$ and In 2 in $5^{3+}$, In 1 and In 3 are pentacoordinated, interacting with only one bipy ligand and featuring three In - In contacts. The peripheral In - In bond lengths only deviate by $5 \mathrm{pm}$ (av. In - In distance $=277.99(14) \mathrm{pm}$ ) and are, with the exception of the In $2-\operatorname{In} 3$ bond of $4^{\mathbf{3}}+, 10$ pm longer than the In - In distances of their triangular congeners. The bridging In $1-\operatorname{In} 3$ distance on the other hand, is with 259.65(12) pm the shortest In - In bond that, to our knowledge, has been reported (the only shorter In - In bond derives from the structural relative seven, see below) (Table 1 and Supplementary Table 15).

Overall and despite the vast literature on compounds containing In - In bonds, the cationic molecular and univalent structures of 4,5 and 6 are unique. Somewhat related to 6 is the $\left[\operatorname{In}_{4}\left\{\mathrm{Cp}_{2} \mathrm{Mo}_{2}(\mathrm{CO})_{4} \mathrm{P}_{2}\right\}_{8}\right]^{4+}\left\{\left[\mathrm{Al}\left(\mathrm{OR}^{\mathrm{F}}\right)_{4}\right]^{-}\right\}_{4}$ salt reported by Scheer et al. ${ }^{26}$ Herein, the $\mathrm{In}^{\mathrm{I}}$ cations form a similar rhombic arrangement, but with intermetallic distances that are at least $60 \mathrm{pm}$ longer (shortest In - In distance: $348.2 \mathrm{pm}$ ). These findings must be due to the different ligand system, as the group used the same $\left[\mathrm{Al}\left(\mathrm{OR}^{\mathrm{F}}\right)_{4}\right]^{-}$anion: that is, the interactions seem to be weakly dispersive rather than covalent. The remaining known
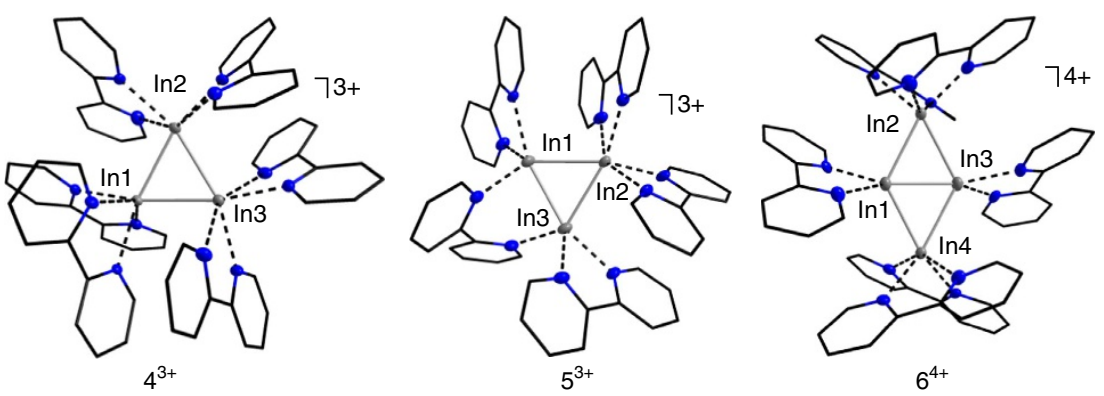

Figure 4 | Molecular structures of indium clusters. Molecular structures of $\left[\ln _{3}(\text { bipy })_{6}\right]^{3+}\left(\mathbf{4}^{\mathbf{3}+}\right),\left[\ln _{3}(\text { bipy })_{5}\right]^{3+}\left(\mathbf{5}^{\mathbf{3}}\right)$ and $\left[\ln _{3}(\text { bipy })_{6}\right]^{4+}\left(\mathbf{6}^{\mathbf{4}+}\right)$. Selected bond lengths are given in pm and angles in ${ }^{\circ}: \mathbf{4}^{\mathbf{3}+}, \ln 1-\ln 2=266.07(4), \ln 1-\ln 3=266.98(5), \ln 2-\ln 3=278.12(5)$, av. $\ln 1-\mathrm{N}=236.9(4)$, av. $\ln 2-N=249.0(4)$, av. $\ln 3-N=246.5(4)$ and $\Varangle(\ln -\ln -\ln )=58.39(12)-62.90(12) ; \mathbf{5}^{\mathbf{3}+}, \ln 1-\ln 2=267.89(5), \ln 1-\ln 3=266.80(5)$, $\ln 2-\ln 3=269.84(5)$, av. $\ln 1-N=233.8(4)$, av. $\ln 2-N=234.0(4)$, av. $\ln 3-N=235.3(4)$ and $\Varangle(\ln -\ln -\ln )=59.49(14)-60.62(14)($ the asymmetric unit of $\mathbf{5}$ contains a second $\left[\ln _{3}{ }_{3}(\text { bipy })_{5}\right]^{3+}$ cluster featuring similar bonds lengths, Supplementary Table 4); $\mathbf{6}^{\mathbf{4}+}, \ln 1-\ln 2=275.93(14)$, $\ln 1-\ln 3=259.65(12), \ln 1-\ln 4=276.62(14), \ln 2-\ln 3=280.83(14), \ln 3-\ln 4=278.56(14)$, av. $\ln 1-N=232.40(10)$, av. $\ln 2-N=236.33(10)$, av. $\ln 3-N=233.60(10)$, av. $\ln 4-N=236.10(10)$ and $\Varangle(\ln -\ln -\ln )=55.59(3)-63.16(4)$ (the asymmetric unit of 6 contains four $\left[\ln _{4}{ }_{4}(\text { bipy })_{6}\right]^{4+}$ clusters, featuring similar $\ln -\ln$ bonds lengths, Supplementary Table 5). The $\left[\mathrm{Al}\left(\mathrm{OR}^{\mathrm{F}}\right)_{4}\right]^{-}$anions and all of the hydrogen atoms were omitted for clarity. The thermal ellipsoids are set at 50\% probability. An alternative representation, featuring ellipsoids for all atoms, is included in Supplementary Fig. 6. 


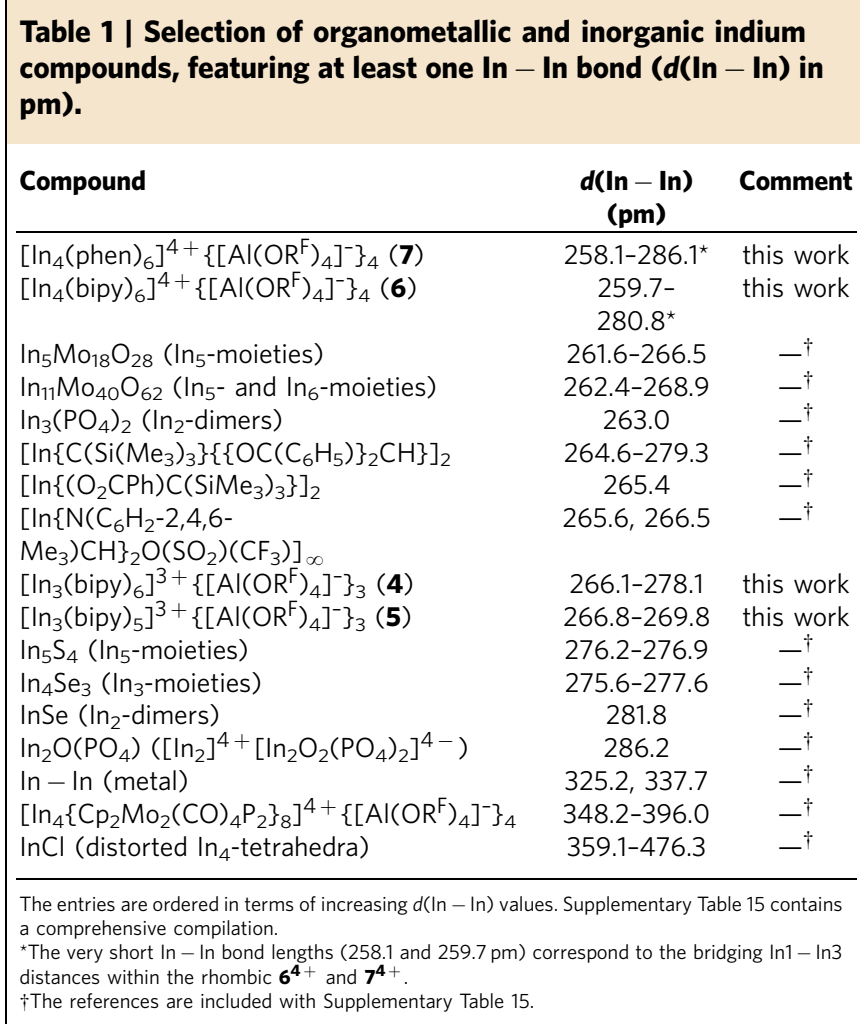

cationic compounds are purely inorganic (cf. Supplementary Table 15) and while some of them feature similar In-In bond lengths, their chain-like substructures differ significantly. Though featuring a related geometry, the reported anionic triangular cyclogallanes differ in their electronic structures: that is, they are only accessible via reductive routes and feature delocalized electrons, resulting in a $2 \pi$-aromatic stabilization ${ }^{54,55}$. The dicationic rhombic tetraborane $\left[\mathrm{B}_{4} \mathrm{H}_{2}(\mu \text {-hpp })_{4}\right]^{2+} \quad(\mathrm{hpp}=$ $1,3,4,6,7,8$-hexahydro- $2 \mathrm{H}$-pyrimido[1,2-a]pyrimidinate) on the other hand, is structurally and electronically related to 6 (ref. 56). Finally, the cationic $\mathrm{In}^{\mathrm{I}}$ clusters are not consistent with the WadeMingos rules (polyhedral skeletal electron pair theory), which are often used to rationalize clusters from group 13 (refs 2,3,57).

Reaction of $\left[\operatorname{In}^{\mathrm{I}}\left(\mathrm{C}_{6} \mathrm{H}_{5} \mathrm{~F}\right)_{2}\right]^{+}\left[\mathrm{Al}\left(\mathrm{OR}^{\mathrm{F}}\right)_{4}\right]^{-}$with phen. While 3 and 4 reproduce the triangular $\left[\mathrm{In}_{3}\right]^{3+}$ motif intrinsically, we additionally applied 1.49 equivalents of 1,10-phenanthroline (phen) to reproduce the rhombic $\left[\mathrm{In}_{4}\right]^{4+}$ motif in $\mathbf{6}^{\mathbf{4}+}$. In doing so, we were able to isolate a structural relative of 6 , that is, the $\left[\operatorname{In}_{4}^{\mathrm{I}}(\text { phen })_{6}\right]^{4+}\left\{\left[\mathrm{Al}\left(\mathrm{OR}^{\mathrm{F}}\right)_{4}\right]^{-}\right\}_{4}$ salt (7) (Fig. 5). The structural parameters of the $\left[\operatorname{In}_{4}{ }_{4}(\text { phen })_{6}\right]^{4+}$ complex $\left(7^{4+}\right)$ resemble those of $6^{4+}$, despite small $\pi-\pi$-interactions within the phen ligands (distances in pm, angles in ${ }^{\circ}$, values for $\mathbf{6}^{\mathbf{4}}$ are parenthesized): av. $\quad$ In - In $=279.55(11) \quad(277.99(14)), \quad \operatorname{In} 1-\operatorname{In} 3=258.06(16)$ (259.65(12)), av. In $-\mathrm{N}=234.15(80)(235.14(10)), \Varangle(\mathrm{In}-\mathrm{In}-$ In $)=54.92(3)-65.11(3)(55.59(3)-63.16(4))$, no In $-F$ contact to the $\left[\mathrm{Al}\left(\mathrm{OR}^{\mathrm{F}}\right)_{4}\right]^{-}$anions. However, with $258.06(16) \mathrm{pm}$ the bridging In 1 - In 3 distance in $7^{\mathbf{4}}$ is the shortest In - In bond length reported to this day. Both, the short bridging $\operatorname{In} 1-\operatorname{In} 3$ distances in $\mathbf{6}^{\mathbf{4}}$ and $7^{4+}$, would be in agreement with the hypothetic interactions of a slightly trans-bent dicationic $[(\mathrm{N} \text {-ligand }) \operatorname{In}=\operatorname{In}(\mathrm{N} \text {-ligand })]^{2+}$ fragment and two $[\operatorname{In}(\mathrm{N}$ ligand $\left.)_{2}\right]^{+}$complexes $(\mathrm{N}$-ligand $=$ bipy, phen), thus resulting in two two-electron three-centre (2e3c) bonds (Fig. 5b).
Apart from 7, the reaction mixture also contained small amounts of a second type of single crystals, which, being colourless and not yellowish, surprisingly corresponded to the $\left[(\mathrm{phen})_{2} \mathrm{In}^{\mathrm{I}}-\right.$ $\left.\mathrm{Ag}^{\mathrm{I}}\left(\mathrm{C}_{6} \mathrm{H}_{5} \mathrm{~F}\right)\right]^{2+}\left\{\left[\mathrm{Al}\left(\mathrm{OR}^{\mathrm{F}}\right)_{4}\right]^{-}\right\}_{2}$ salt (8). To our knowledge, this is the first monomeric dicationic In $-\mathrm{Ag}$ adduct. While the $\mathrm{Ag}^{\mathrm{I}}$ cation likely derives from the originally used $\mathrm{Ag}^{+}\left[\mathrm{Al}\left(\mathrm{OR}^{\mathrm{F}}\right)_{4}\right]^{-}$ salt (stemming from the synthesis of (2), the $\left[(\text { phen })_{2} \mathrm{In}^{\mathrm{I}}-\right.$ $\left.\operatorname{Ag}^{\mathrm{I}}\left(\mathrm{C}_{6} \mathrm{H}_{5} \mathrm{~F}\right)\right]^{2+}$ complex $\left(\mathbf{8}^{\mathbf{2}+}\right)$ can be considered as an addition product of the Lewis basic, tetragonal pyramidal coordinated $\left[\operatorname{In}^{\mathrm{I}}(\text { phen })_{2}\right]^{+}$complex and the Lewis acidic, $\eta^{3}$-coordinated $\left[\mathrm{Ag}^{\mathrm{I}}\left(\mathrm{C}_{6} \mathrm{H}_{5} \mathrm{~F}\right)\right]^{+}$complex (cf. $\Delta_{\mathrm{r}} H^{\circ}$ (gas) $=-73 /-84 \mathrm{~kJ} \mathrm{~mol}^{-1}$ and $\Delta_{\mathrm{r}} G^{\circ}$ (gas) $=-24 /-36 \mathrm{~kJ} \mathrm{~mol}^{-1}$ for the formation of this gaseous dication (!) at $298.15 \mathrm{~K}, 1.0 \mathrm{bar}, \mathrm{BHLYP} / \mathrm{SV}(\mathrm{P})$ and $\mathrm{B} 3 \mathrm{LYP} / \mathrm{SV}(\mathrm{P})$ level). Yet, multi-charged species in the gas phase are subject to strong repulsion and Coulomb explosion (v.s.). Thus, the surprisingly favourable $\Delta_{\mathrm{r}} H^{\circ}$ (gas) and $\Delta_{\mathrm{r}} G^{\circ}$ (gas) values for the formation of $\mathbf{8}^{\mathbf{2}}$ are probably attributable to the high Lewis basicity of the $\left[\operatorname{In}^{\mathrm{I}}(\text { phen })_{2}\right]^{+}$complex. Fig. 6 contains the singlecrystal structure as well as the highest occupied molecular orbital of the converged calculated $\mathbf{8}^{2+}$ structure.

Multinuclear solution NMR spectroscopy. All obtained single crystals were dissolved in $o-\mathrm{C}_{6} \mathrm{H}_{4} \mathrm{~F}_{2}$ and investigated by ${ }^{1} \mathrm{H},{ }^{14} \mathrm{~N}$, ${ }^{19} \mathrm{~F},{ }^{27} \mathrm{Al},{ }^{71} \mathrm{Ga}$ and ${ }^{115} \mathrm{In}$ NMR spectroscopy. While the ${ }^{14} \mathrm{~N}$, ${ }^{71} \mathrm{Ga}$ and ${ }^{115} \mathrm{In}$ NMR spectra featured no resonances, thus being in good agreement with earlier reported $\sigma$-coordinated complexes of $\mathrm{Ga}^{\mathrm{I}}$ and $\mathrm{In}^{\mathrm{I}} 28,29,31,32$, one singlet in the ${ }^{19} \mathrm{~F}$ NMR and ${ }^{27} \mathrm{Al}$ NMR spectra at -74.9 p.p.m. and +33.8 pm, respectively, revealed the intactness of the $\left[\mathrm{Al}\left(\mathrm{OR}^{\mathrm{F}}\right)_{4}\right]^{-}$anions ${ }^{58}$. In the case of the mixed crystalline residue of 7 and 8 , the ${ }^{19}$ F NMR spectrum additionally featured the triplet of a triplet at -113 p.p.m. assigned to $\mathrm{C}_{6} \mathrm{H}_{5} \mathrm{~F}$, which likely derives from $\mathbf{8}^{\mathbf{2}}$. Finally, the ${ }^{1} \mathrm{H}$ NMR spectra provided primary information on the stability of the obtained cationic complexes in solution: that is, the solution of $\mathbf{3}$ featured very weak and broad resonances due to the paramagnetic nature of $\mathbf{3}^{2+}$ (cf. EPR studies). Solutions of 4, 5 and 6 featured multiplets attributable to solvated bipy, thus speaking for a fragmentation of the cationic indium clusters in solution. The solution of the crystalline residue of 7 and $\mathbf{8}$ yielded a complex multiplet pattern in the aromatic region, which likely is attributable to different fragments of both sets of single crystals. From the multinuclear NMR studies we suggest that the cationic In $^{\mathrm{I}}$ clusters are unstable in solution, while the $\left[\mathrm{Al}\left(\mathrm{OR}^{\mathrm{F}}\right)_{4}\right]^{-}$anions stay intact. The dissociation of the cationic $\mathrm{In}^{\mathrm{I}}$ clusters is probably attributable to the distinct Coulomb repulsion of the $\mathrm{In}-\mathrm{In}$ bonded individual $\left[\operatorname{In}^{\mathrm{I}}(\mathrm{N} \text {-Ligand })_{1,2}\right]^{+}$ units constituting $\mathbf{4}^{\mathbf{3}+}, \mathbf{5}^{\mathbf{3}+}, \mathbf{6}^{\mathbf{4}+}$ and $\mathbf{7}^{\mathbf{4}+}$ (cf. DFT studies below).

Disproportionation versus cationic cluster formation. To answer the question why $\mathbf{1}$ in the presence of bipy disproportionates and $\mathbf{2}$ functions as indium cluster source, as well as to elaborate a potential reaction pathway, we conducted further DFT calculations. From a retrosynthetic point of view, we chose the $\left[\mathrm{M}^{\mathrm{I}}(\text { bipy })_{2}\right]^{+}$complex $(\mathrm{M}=\mathrm{Ga}, \mathrm{In})$ as starting point, as the latter seems to be a crucial building block during the disproportionation and cluster formations: that is, in $\mathbf{4}^{\mathbf{3}+}, \mathbf{5}^{\mathbf{3}+}$ and $\mathbf{6}^{\mathbf{4}+}$, six out of ten $\mathrm{In}^{\mathrm{I}}$ cations are coordinated in such a manner. While this assumption is supported by the successful isolation of $7^{\mathbf{4}}$ and $\mathbf{8}^{\mathbf{2}}$, the question remains, how the fragments interact with each other? (i) Via an ambiphilic route in which each $\left[\mathrm{M}(\text { bipy })_{2}\right]^{+}$ complex functions as a Lewis acid (empty $4 \mathrm{p} / 5 \mathrm{p}$ orbitals) and as a Lewis base (occupied $4 \mathrm{~s} / 5 \mathrm{~s}$ orbitals) (cf. the cyclopropane derivatives of the group 13 (ref. 59) and 14 homologues ${ }^{60}$ ) or ii) via a singlet-triplet route, that is, ligands such as $o$-quinones, $\mathrm{N}$-hetero 


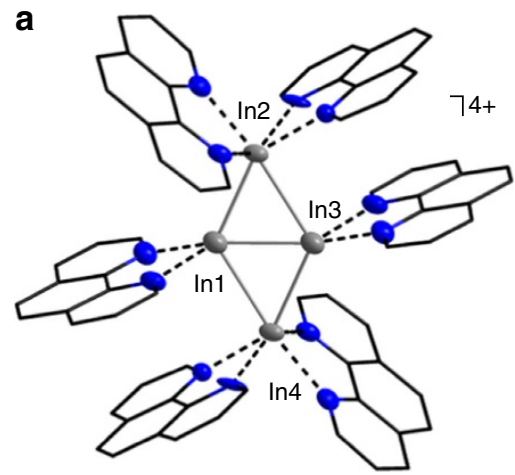

b

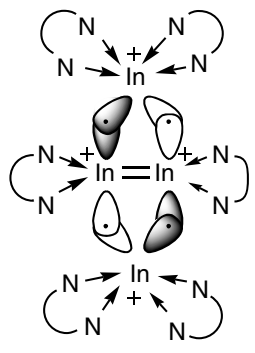

C

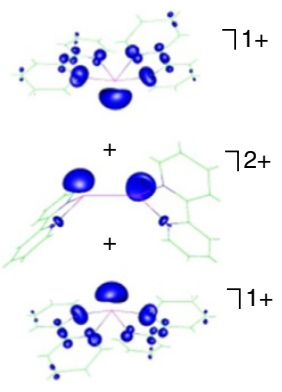

Figure 5 | Molecular structure and bonding description of $\left[\ln _{4}^{1}(\text { phen })_{6}\right]^{4+}\left(7^{4+}\right)$ as well as spin density distributions of potential precursors. (a) Molecular structure of $\mathbf{7}^{\mathbf{4}}$. Selected bond lengths are given in pm, angles in ${ }^{\circ}$ and the values for $\mathbf{6}^{\mathbf{4}+}$ are parenthesized: $\ln 1-\ln 2=273.03(10)$ (275.93(14)), $\ln 1-\ln 3=258.06(16)(259.65(12)), \ln 1-\ln 4=286.06(11)(275.93(14)), \ln 2-\ln 3=286.06(11)(280.83(14)), \ln 3-\ln 4=273.03(10)$ (278.56(14)), av. $\ln 1-\mathrm{N}=231.2(9)(232.40(10))$, av. $\ln 2-\mathrm{N}=235.6(8)(236.33(10))$, av. $\ln 3-\mathrm{N}=231.2(9)(233.60(10))$, av. $\ln 4-\mathrm{N}=235.6(8)$ $(236.10(10))$ and $\Varangle(\ln -\ln -\ln )=54.92(3)-65.11(3)(55.59(3)-63.16(4))$. The $\left[\mathrm{Al}\left(\mathrm{OR}^{\mathrm{F}}\right)_{4}\right]^{-}$anions and all of the hydrogen atoms were omitted for clarity. (b) A possible hypothetic description of the bonding situation in $\mathbf{6}^{\mathbf{4}+}$ and $\mathbf{7}^{\mathbf{4}}+$. The short bridging $\ln 1-\ln 3$ values could originate from interactions between the $\pi^{*}$-orbitals of a dicationic, formally doubly bonded $[(\mathrm{N} \text {-ligand }) \ln =\ln (\mathrm{N} \text {-ligand })]^{2+}$ fragment ( $\mathrm{N}$-ligand $=$ bipy, phen) and singly occupied orbitals of two $\left[\ln (\mathrm{N} \text {-ligand })_{2}\right]^{+}$complexes, thus resulting in two two-electron three-centre bonds (2e3c), partially, but not fully, populating the antibonding $\pi^{\star}$-orbital. The remaining small $\ln =\ln$ double-bonding contribution could account for the observed short $\ln -\ln$ separations in $\mathbf{6}^{\mathbf{4}+}$ and $\mathbf{7}^{\mathbf{4}+}$ and also the relatively long $2 \mathrm{e} 3 \mathrm{c} \ln -\ln$ bonds to the upper and lower $\left[\ln (\mathrm{N} \text {-ligand })_{2}\right]^{+}$moieties. c) Calculated spin density distributions of triplet state fragments that could interact to form the observed cationic clusters (spin density cutoff at 0.010 a.u., B3LYP/SV(P) level). In the calculated $\left[\right.$ (bipy) $\ln =\ln (\text { bipy) }]^{3+}$ fragment, the $\ln -$ In distance is $291.4 \mathrm{pm}$ and the average spin density on each indium atom $77 \%$ (a planar dicationic fragment did not converge, even if the conductor-like screening model $(\operatorname{COSMO})^{65}$ was switched on and the permittivity was set to infinite $\left.\varepsilon_{\mathrm{r}}=\infty\right)$. For triplet state of $\left[\ln (\text { bipy })_{2}\right]^{+}$, the spin density on the indium atom is $35 \%$.

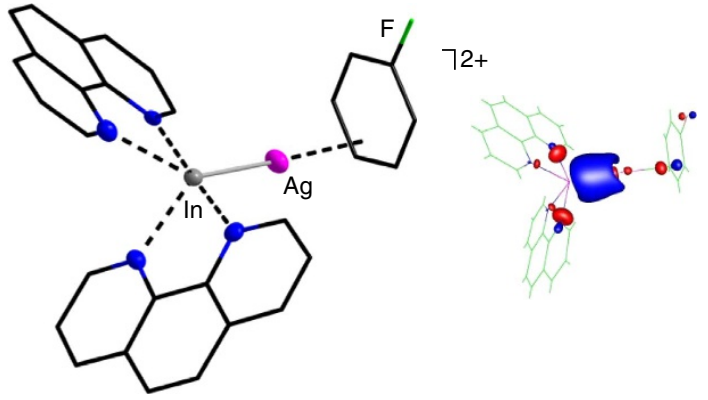

Figure 6 | Molecular structure of $\left[(\text { phen })_{2} \ln ^{\prime}-\mathbf{A g}^{\prime}\left(\mathrm{C}_{6} \mathrm{H}_{5} \mathrm{~F}\right)\right]^{2+}\left(8^{2+}\right)$. Selected bond lengths are given in $\mathrm{pm}$ and angles in ${ }^{\circ}$ : av. $\ln -\mathrm{N}=233.3(3), \ln -\mathrm{Ag}=256.37(5), \mathrm{Ag}-\mathrm{cent}=239.4$ and In $-\mathrm{Ag}-$ cent $=173.0$ (cent $=$ centroid of the $\eta^{3}$-coordinating $\mathrm{C}_{6} \mathrm{H}_{5} \mathrm{~F}$; the linearity is in good agreement with earlier reported systems ${ }^{70}$ ). The $\left[\mathrm{Al}\left(\mathrm{OR}^{\mathrm{F}}\right)_{4}\right]^{-}$anions and all of the hydrogen atoms were omitted for clarity. The thermal ellipsoids are set at $50 \%$ probability. An alternate formulation as $\left[(\text { phen })_{2} \ln ^{\prime}-\operatorname{In}^{\prime}\left(\mathrm{C}_{6} \mathrm{H}_{5} \mathrm{~F}\right)\right]^{2}+$ diindane is not conceivable, as a $\left[\operatorname{In}^{\prime}\left(\mathrm{C}_{6} \mathrm{H}_{5} \mathrm{~F}\right)\right]^{+}$complex would be $\eta^{6}$-coordinated. In addition, the X-ray diffraction refinement of the diindane formulation gave inferior $\mathrm{R}$-factors and the DFT structure refinement did not converge. As an inset, the figure also contains the highest occupied molecular orbital (HOMO) of the converged $\mathbf{8}^{\mathbf{2}+}$ structure. The latter features a constructive interaction between the occupied $5 \mathrm{~s}$ orbital of the $\left[\ln ^{\prime}(\text { phen })_{2}\right]^{+}$complex and the unoccupied $5 \mathrm{~s} / 4 \mathrm{~d}_{\mathrm{z}} 2$ hybrid orbital ${ }^{70}$ of the $\left[\mathrm{Ag}^{\mathrm{l}}\left(\mathrm{C}_{6} \mathrm{H}_{5} \mathrm{~F}\right)\right]^{+}$complex. The calculated distances are in good agreement with experimental results (bond lengths in pm and angles in ${ }^{\circ}$ ): av. $\ln -\mathrm{N}=235.1, \ln -\mathrm{Ag}=262.2$,

$\mathrm{Ag}-$ cent $=253.4$ and $\mathrm{In}-\mathrm{Ag}-$ cent $=175.0(\mathrm{~B} 3 \mathrm{LYP} / \mathrm{SV}(\mathrm{P})$ level, electron density cutoff at 0.06 a.u.).

arenes and diazabutadienes have proven to be non-innocent ${ }^{61}$, thus promoting electron transfer reactions and a more easy access to the triplet states of the complexes ${ }^{62}$ (Fig. 7).
From an energetic point of view, the singlet-triplet route appears to be more conceivable, as the singlet-triplet gaps are distinctively smaller than the corresponding $4 \mathrm{~s} / 5 \mathrm{~s}-4 \mathrm{p} / 5 \mathrm{p}$ energy gaps (Table 2 ; cf. DFT studies by Macdonald et al. ${ }^{63}$ ). In addition and considering the distribution of spin densities, the triplet states of the $\left[\mathrm{M}(\text { bipy })_{2}\right]^{+}$complexes offer important insights into the metal-dependent redox stabilities: that is, for gallium the tetrahedral $\left[\mathrm{Ga}^{3+}\left\{(\text { bipy })^{-}\right\}_{2}\right]^{+}$complex forms and for indium the tetragonal pyramidal $\left[\operatorname{In}^{2+}(\text { bipy })(\text { bipy })^{-}\right]^{+}$ complex. Hence, only the latter should be able to stepwise cyclotrimerize, while the former is labile and disproportionates. In this context, the choice of the redox-active ligand is crucial and for indium, bipy seems to be the perfect match as it enables reversible, single electron transfers between the metal centre and the ligand, thus making way for the stepwise cationic metal atom cluster formation. For gallium, this is not the case and the bipy-located electrons are prone to intermolecular rather than intramolecular transfer reactions, resulting in a disproportionation of the $\left[\mathrm{Ga}(\text { bipy })_{2}\right]^{+}$complex $^{64}$.

Finally, we attempted to calculate the molecular structures of $4^{3+}, 5^{3+}$ and $6^{4+}$. Though we implemented the conductor-like screening model ${ }^{65}$ with an infinite permittivity and dispersive interactions (D3), the cationic In clusters fragmented due to the distinct Coulomb repulsion. However, we were able to calculate dicationic cluster fragments in their triplet state, such as $\left[(\text { bipy })_{2} \operatorname{In}-\operatorname{In}(\text { bipy })_{2}\right]^{2+}$ (Fig. 7 , inset). With an average spindensity distribution of $32 \%$ at each indium atom, the latter could be seen as a reaction intermediate of the univalent indium clusters, thus supporting a stepwise cluster formation (for further dicationic cluster fragments see Supplementary Fig. 10). Furthermore, we assessed the gas-phase thermodynamics $\left(\Delta_{\mathrm{r}} H^{\circ}\right.$ (gas), Table 3$)$ of the formations of $\mathbf{4}^{\mathbf{3}+}, \mathbf{5}^{\mathbf{3}+}$ and $\mathbf{6}^{\mathbf{4}+}$ from BHFCs and setting $\Delta_{\mathrm{r}} H^{\circ}$ (solid) in a worst-case scenario to $\pm 0 \mathrm{~kJ} \mathrm{~mol}^{-1}$ (Supplementary Fig. 8). The endothermic values are attributable to the above mentioned Coulomb repulsion and very well correspond to the large exothermicity of the Coulomb 


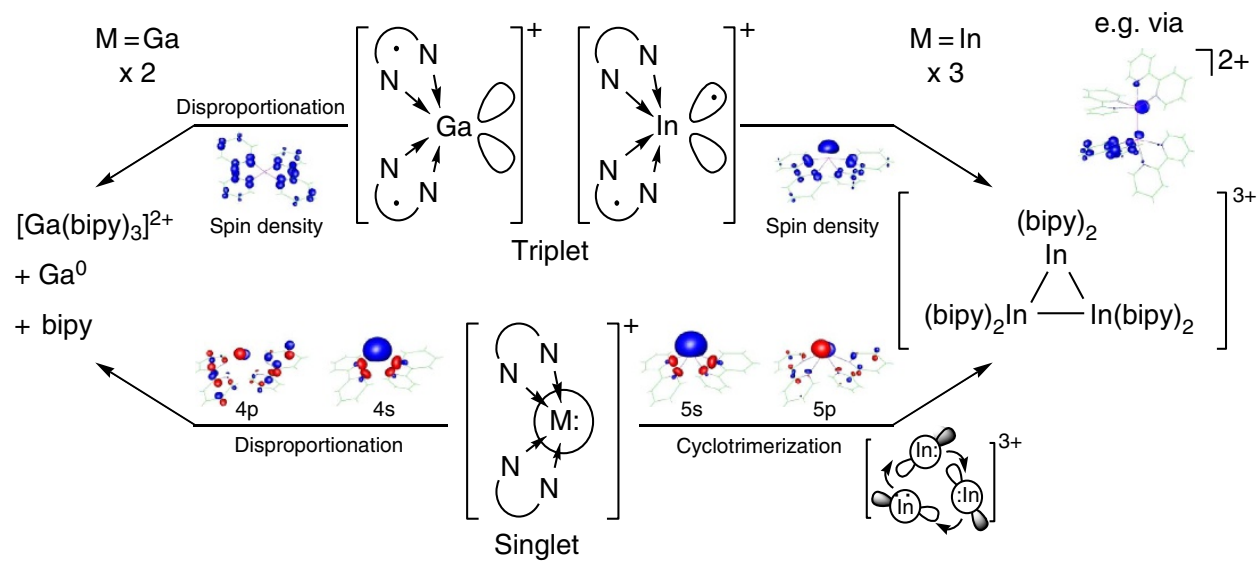

Figure $\mathbf{7}$ | Metal-dependent behaviour of $\left[\mathbf{M}^{\prime}\left(\mathbf{C}_{\mathbf{6}} \mathbf{H}_{\mathbf{5}} \mathbf{F}\right)_{\mathbf{2}}\right]^{+}\left[\mathbf{A I}\left(\mathbf{O R}^{\mathbf{F}}\right)_{\mathbf{4}}\right]^{-}(\mathbf{M}=\mathbf{G a}$, In) in the presence of bipy. Disproportionation (for $\mathrm{M}=\mathrm{Ga})$ and cluster formation (for $M=\ln$ ) can occur via (i) an ambiphilic singlet route (bottom) or (ii) a triplet route (top). Regarding (i), the $\left[\mathrm{M}^{\prime}(\text { bipy) }]^{+}{ }^{+}\right.$complexes feature an occupied $4 \mathrm{~s} / 5 \mathrm{~s}$-orbital (HOMO) and empty $4 \mathrm{p} / 5 \mathrm{p}$-orbitals (LUMO +6 ), thus being able to react via a disproportionation or a cyclotrimerization, yielding $\mathbf{3}^{\mathbf{2}+}$ and $\mathbf{4}^{\mathbf{3}+}$, respectively. The conceivability of this reaction path directly correlates to the energy gap between the $4 \mathrm{~s} / 5 \mathrm{~s}$ and the $4 p / 5 p$-orbitals of the reactants (Table 2 ). Choosing reaction path (ii), the $\left[\mathrm{M}^{\prime}(\text { bipy })_{2}\right]^{+}$complexes react via their triplet state. Dependent on the metal, the latter significantly differ in terms of geometries and localization of spin densities. Hence, the $\left[\mathrm{Ga}\left(\text { bipy) }{ }_{2}\right]^{+}\right.$complex changes its coordination mode from tetragonal pyramidal in the singlet to tetrahedral in the triplet state and both unpaired electrons are equally distributed over the bipy ligands (spin density at the gallium atom $=6.0 \%$ ). These findings clearly speak for the tendency of the Gal cations to disproportionate and also explain the complex's inability to form a di-/oligo-gallane. ${ }^{44}$ The $\left[\ln (\text { bipy })_{2}\right]^{+}$complex on the other hand, retains its tetragonal pyramidal coordination mode and $35 \%$ of the spin density is located on the indium atom, making a stepwise cyclotrimerization feasible (cf. the dicationic $\left[(\text { bipy) })_{2} \ln -\ln (\text { bipy })_{2}\right]^{2+}$ cluster fragment shown). The conceivability of the reaction path directly correlates to the singlet-triplet gaps of the reactants (Table 2). The Kohn-Sham orbitals shown were selected on localization of the electron density on the metal cations and the lowest possible energy (electron and spin density cutoffs at 0.06 and 0.01 a.u., B3LYP/SV (P) level; as shown in Supplementary Fig. 10, the $\left[(\text { bipy })_{2} \ln -\ln (\text { bipy })_{2}\right]^{2+}$ cluster fragment only featured a spin density at the indium atoms, if the BHLYP functional was applied).

\section{Table 2 | Energy gaps between the occupied $4 \mathrm{~s} / 5 \mathrm{~s}-$ and unoccupied $4 \mathrm{p} / 5 \mathrm{p}$-orbitals as well as singlet-triplet gaps of $\left[M\left(\mathrm{C}_{6} \mathrm{H}_{5} \mathbf{F}\right)_{2}\right]^{+},[\mathrm{M}(\mathrm{bipy})]^{+}$and $\left[\mathrm{M}(\mathrm{bipy})_{2}\right]^{+}$in $\mathrm{kJ} \mathrm{mol}^{-1}$ ( $M=G a$, In; gas phase, 298.15 K, 1.0 bar, values at BHLYP/ SV(P)/B3LYP/SV(P) level).}

\begin{tabular}{|c|c|c|c|c|}
\hline & \multicolumn{2}{|c|}{$\Delta E\left(\mathrm{~kJ} \mathrm{~mol}^{-1}\right)(M=\mathrm{Ga})$} & \multicolumn{2}{|c|}{$\Delta E\left[k J \mathrm{~mol}^{-1}\right](M=\mathrm{In})$} \\
\hline & $4 s / 4 p$ & singlet-triplet & $5 s / 5 p$ & singlet-triplet \\
\hline $\begin{array}{l}{ }_{\left[\mathrm{M}\left(\mathrm{C}_{6} \mathrm{H}_{5} \mathrm{~F}\right)_{2}\right]^{+}} \\
{[\mathrm{M}(\text { bipy })]^{+}} \\
{\left[\mathrm{M}(\text { bipy })_{2}\right]^{+}}\end{array}$ & $\begin{array}{l}853 / 653 \\
582 / 386 \\
709 / 507\end{array}$ & $\begin{array}{c}311 /-^{\star} \\
196 /-^{\dagger} \\
5^{\ddagger} / 21^{\ddagger}\end{array}$ & $\begin{array}{l}797 / 618 \\
580 / 383 \\
645 / 471\end{array}$ & $\begin{array}{c}-{ }_{1} /-^{\dagger} \\
227 /-^{\dagger} \\
111^{\S} / 96^{\S}\end{array}$ \\
\hline $\begin{array}{l}\text { *Even after } 500 \text { itera } \\
\dagger \text { Though the geomet } \\
\text { not correctly describ } \\
\text { †The significant decr } \\
\text { complex from a tetra } \\
\text { state, respectively }(S \\
\left.\$ \text { She }[\text { In (bipy) })_{2}\right]^{+} \\
\text {singlet and the triple }\end{array}$ & $\begin{array}{l}\text { optimization } \\
\text { e of } \Delta E \text { is ac } \\
\text { lal pyramidal } \\
\text { blementary } T \\
\text { lex features } \\
\text { cate (Supplem }\end{array}$ & $\begin{array}{l}\text { onverged, the electro } \\
\text { ompanied by a geon } \\
\text { b tetrahedral coord } \\
\text { ble } 12 \text { ). } \\
\text { tetragonal pyramid } \\
\text { entary Table } 12 \text { ). }\end{array}$ & on mode in $t$ & $\begin{array}{l}\text { te did not converge. } \\
\text { f the triplet state is } \\
\text { he }\left[G a(b i p y)_{2}\right]^{+} \\
\text {e singlet and triplet } \\
\text { ode both in the }\end{array}$ \\
\hline
\end{tabular}

explosion of $\mathbf{4}^{\mathbf{3}+}$ with formation of three $\left[\operatorname{In}(\text { bipy })_{2}\right]^{+}$ monocations in the gas phase and assessed via a suitable BHFC as $-466 \mathrm{~kJ} \mathrm{~mol}^{-1}$ (Table 3 and Supplementary Fig. 8).

This is in agreement with single-point DFT calculations on the frozen conformation of solid $\mathbf{4}^{\mathbf{3}}$, Coulomb exploding to give three $\left[\operatorname{In}(\text { bipy })_{2}\right]^{+}$monocations cut out of this cyclic trimer solidstate structure. B3LYP and BHLYP suggest this gas phase process to be favoured by -684 and $-705 \mathrm{~kJ} \mathrm{~mol}^{-1}$, respectively. A nonligand- supported triangular $\left[\mathrm{In}_{3}\right]^{3+}$ cluster $\left(d_{\mathrm{In}-\mathrm{In}}=270 \mathrm{pm}\right)$ was calculated to Coulomb explode at the same level with $-1,447 /-$ $1,459 \mathrm{~kJ} \mathrm{~mol}^{-1}$, Supplementary Table 13). Overall, the formation of the ligand supported $\left[\operatorname{In}_{3}\right]^{3+} /\left[\operatorname{In}_{4}\right]^{4+}$ clusters seems to be only
Table 3 I Estimated $\Delta_{\mathrm{r}} \mathrm{H}^{\circ}$ (gas) values for the formation of $4^{3+}, 5^{3+}$ and $6^{4+}$ as well as for the Coulomb explosion of

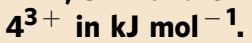

\section{Gas phase reaction}

$3\left[\ln (\mathrm{PhF})_{2}\right]^{+}+6$ bipy $\rightarrow\left[\ln _{3}(\text { bipy })_{6}\right]^{3+}+6 \mathrm{PhF}$

$3\left[\ln (\mathrm{PhF})_{2}\right]^{+}+5$ bipy $\rightarrow\left[\ln _{3}(\text { bipy })_{5}\right]^{3+}+6 \mathrm{PhF}$

$4\left[\ln (\mathrm{PhF})_{2}\right]^{+}+6$ bipy $\rightarrow\left[\ln _{4} \text { (bipy) }\right]^{4+}+8 \mathrm{PhF}$

$\left[\ln _{3}(\text { bipy })_{6}\right]^{3+} \rightarrow 3\left[\ln (\text { bipy })_{2}\right]^{+}$

$\Delta_{\mathrm{r}} \mathrm{H}^{\circ}$ (gas)

$\left[\mathrm{kJ} \mathrm{mol}^{-1}\right]$

$+164$

$+252$

$+731$

$-466$

The $\Delta_{\mathrm{r}} \mathrm{H}^{\circ}$ (solid) values for all BHFCs were deliberately set to $\pm 0 \mathrm{~kJ} \mathrm{~mol}^{-1}$, the $\Delta_{\text {latt }} H^{\circ}$ values calculated by applying the Jenkins generalized Kapustinskii equation ${ }^{66}$ and all other enthalpies extrapolated from the given references (Supplementary Fig. 8).

possible through the application of matching ligands and ultimately is a solid-state-driven phenomenon. Both, bipy and phen lead to a pronounced decrease of the Coulomb repulsion within the clusters by diluting the positive charges on the $\mathrm{In}^{+}$ cations to the ligand backbone, and contributing enough negative charge to yield ligand stabilized $\left[\mathrm{In}_{3}\right]^{3+}\left(\mathrm{A}^{-}\right)_{3}$ and $\left[\mathrm{In}_{4}\right]^{4+}\left(\mathrm{A}^{-}\right)_{4}$ salts with short In - In bonds. This corresponds to a ligand-tometal charge transfer. The calculated high $\Delta_{\text {latt }} H^{\circ}$ values of $-1,438 \quad(4), \quad-1,444(5)$ and $-2,266 \mathrm{~kJ} \mathrm{~mol}^{-1}$ (6) further stabilize the salts ${ }^{66}$. Together, the charge transfer leading to favourable metal-metal bond strengths, in combination with the lattice enthalpy gain are sufficient to overcome the strong Coulomb repulsion active in gaseous and solution phases. Last, it should be noted that for the central $\left[\mathrm{In}_{4}\right]^{4+}$ cluster core with eight valence electrons deriving from four $\operatorname{In}^{\mathrm{I}}$ cations, the stability of $6^{4+}$ and $7^{4+}$ would be in agreement with the Jellium model ${ }^{67}$. 


\section{Discussion}

The reaction of $\mathbf{1}$ and 2,2'-bipyridine resulted in a disproportionation of the former, thus yielding the monomeric and paramagnetic $\left[\mathrm{Ga}(\text { bipy })_{3}\right]^{2+} \bullet$ complex. Herein, the gallium cation is coordinated in a distorted octahedral fashion, and EPR and DFT studies reveal a ligand-centred radical: that is, a $\left.\left[\mathrm{Ga}^{\mathrm{III}}\{\text { (bipy) })_{3}\right\}^{\bullet}\right]^{2+}$ complex. Applying the heavier homologue 2 on the other hand, we isolated the first homonuclear cationic triangular and rhombic clusters of univalent indium: $\left[\operatorname{In}_{3}^{\mathrm{I}}(\mathrm{bipy})_{6}\right]^{3+}, \quad\left[\operatorname{In}_{3}^{\mathrm{I}}(\text { bipy })_{5}\right]^{3+}, \quad\left[\operatorname{In}_{4}^{\mathrm{I}}(\text { bipy })_{6}\right]^{4+} \quad$ and $\left[\operatorname{In}_{4}{ }_{4}(\text { phen })_{6}\right]^{4+}$. Herein, the $\operatorname{In}^{\mathrm{I}}$ cations are coordinated by one, 1.5 or two chelating bipy/phen ligands. To our knowledge, the In - In distances (258.1 and $259.7 \mathrm{pm})$ within the In - In bridges in the rhombic clusters are the shortest that have been reported so far. DFT studies suggest a stepwise formation of the clusters via their triplet state and an alternate ambiphilic route seems to be energetically less favourable. The general driving force for this cationic cluster formation is attributable to relatively strong In - In bonds, reduction of Coulomb repulsion by introduction of a suitable ligand and ligand-to-metal charge transfer in combination with the high lattice enthalpies of the resultant ligand stabilized $\left[\mathrm{M}_{3}\right]^{3+}\left(\mathrm{A}^{-}\right)_{3}$ and $\left[\mathrm{M}_{4}\right]^{4+}\left(\mathrm{A}^{-}\right)_{4}$ salts. We are convinced that this is a general phenomenon, which could be used as a pathway to cationic metal atom cluster formation of subvalent metal cations in combination with strong but sterically accessible (chelating?) ligands.

\section{Methods}

General experimental procedures. All manipulations were performed using Schlenk or glove box techniques in an argon atmosphere $\left(\mathrm{H}_{2} \mathrm{O}\right.$ and $\mathrm{O}_{2}<1$ p.p.m.). $o-\mathrm{C}_{6} \mathrm{H}_{4} \mathrm{~F}_{2}$ and $\mathrm{C}_{6} \mathrm{H}_{5} \mathrm{~F}$ were dried over $\mathrm{CaH}_{2}$, distilled and had $\mathrm{H}_{2} \mathrm{O}$ contents below 5 p.p.m. (Karl-Fischer titrations). Because the obtained compounds contain large amounts of fluorine in chemically very stable $\mathrm{CF}_{3}$ groups, standard combustion analyses have proven to be incomplete. Characterizations of novel compounds were therefore done on the basis of single-crystal X-ray analysis and multinuclear NMR spectroscopy. As the highly symmetric and perfluorinated $\left[\mathrm{Al}\left(\mathrm{OR}^{\mathrm{F}}\right)_{4}\right]^{-}$anions are usually heavily disordered, prone to crystallize in superstructures (cf. compound 3) and, due to their bulkiness, able to add up to very large unit cells (the unit cell sizes of $\mathbf{6}$ and the protein Viscotoxin B are comparable, Supplementary Table 8), processing of the crystal structure data were everything else than trivial. In this context, however, the quality of the data which were collected using a completely up to date crystallography is clearly well within the limits of accepted standards, thus allowing us to unambiguously identify all structures. Moreover, all compounds were reproduced from independent syntheses (apart from 5 and 6) and 4, 5, 6 and 7 intrinsically confirm the central structural triangular $\left[\operatorname{In}_{3}\right]^{3+}$ and rhombic $\left[\mathrm{In}_{4}\right]^{4+}$ motifs. Therefore, access to international facilities for better quality X-ray diffraction data were not sought for. Further details are included in the Supporting Information. Moreover, it was several times attempted to obtain ESI-MS data of the reported systems. As the ionic compounds are very sensitive however, no meaningful spectra were obtained-presumably due to oxidation and/or hydrolysis on the way to the ionization chamber (as very frequently encountered with our sensitive systems). Since the other investigations strongly suggested these multiply charged cations to only exist in the solid state, this method was not further pursued. Compound $\mathbf{3}$ was additionally characterized by EPR and ultravioletvisible measurements. The DFT calculations were performed at the BHLYP/SV(P) and $\mathrm{B} 3 \mathrm{LYP} / \mathrm{SV}(\mathrm{P})$ level of theory.

\section{References}

1. Cotton, F. A. Transition-metal compounds containing clusters of metal atoms. Q. Rev. Chem. Soc. 20, 389-401 (1966).

2. Wade, K. The structural significance of the number of skeletal bonding electron-pairs in carboranes, the higher boranes and borane anions, and various transition-metal carbonyl cluster compounds. J. Chem. Soc. D 792-793 (1971).

3. Welch, A. J. The significance and impact of Wade's rules. Chem. Commun. 49, 3615-3616 (2013).

4. Corbett, J. D. Polyanionic Clusters and Networks of the Early p-Element Metals in the Solid State: Beyond the Zintl Boundary. Angew. Chem. Int. Ed. 39, 670-690 (2000).

5. Anson, C. E. et al. Synthesis and crystal structures of the ligand-stabilized silver chalcogenide clusters $\left[\mathrm{Ag}_{154} \mathrm{Se}_{77}(\mathrm{dppxy})_{18}\right],\left[\mathrm{Ag}_{320}(\mathrm{~S} t \mathrm{Bu})_{60} \mathrm{~S}_{130}(\mathrm{dppp})_{12}\right]$,

$\left[\mathrm{Ag}_{352} \mathrm{~S}_{128}\left(\mathrm{StC}_{5} \mathrm{H}_{11}\right)_{96}\right]$, and $\left[\mathrm{Ag}_{490} \mathrm{~S}_{188}\left(\mathrm{StC}_{5} \mathrm{H}_{11}\right)_{114}\right]$. Angew. Chem. Int. Ed. 47, 1326-1331 (2008).
6. Schnöckel, H. \& Schnepf, A. in The Group 13 Metals Aluminium, Gallium, Indium and Thallium: Chemical Patterns and Peculiarities 402-487 (John Wiley \& Sons, Ltd, 2011).

7. Schnöckel, H. Structures and properties of metalloid al and ga clusters open our eyes to the diversity and complexity of fundamental chemical and physical processes during formation and dissolution of metals. Chem. Rev. 110, 4125-4163 (2010).

8. Masuda, J. D., Schoeller, W. W., Donnadieu, B. \& Bertrand, G. NHC-mediated aggregation of $\mathrm{P}_{4}$ : isolation of a $\mathrm{P}_{12}$ cluster. J. Am. Chem. Soc. 129, 14180-14181 (2007).

9. Dohmeier, C., Loos, D. \& Schnöckel, H. Aluminum(I) and gallium(I) compounds: syntheses, structures, and reactions. Angew. Chem. Int. Ed. Engl. 35, 129-149 (1996).

10. Jurca, T., Hiscock, L. K., Korobkov, I., Rowley, C. N. \& Richeson, D. S. The tipping point of the inert pair effect: experimental and computational comparison of $\mathrm{In}(\mathrm{I})$ and $\mathrm{Sn}(\mathrm{II})$ bis(imino)pyridine complexes. Dalton Trans. 43, 690-697 (2014).

11. Van Den Berg, J. M. The crystal structure of the room temperature modification of indium chloride, InCl. Acta. Crystallogr. 20, 905-910 (1966).

12. van der Vorst, C. P. J. M., Verschoor, G. C. \& Maaskant, W. J. A. The structures of yellow and red indium monochloride. Acta Crystallogr., Sect. B: Struct. Sci. 34, 3333-3335 (1978).

13. Brukl, A. \& Ortner, G. Die Sulfide des Galliums. Monatsh. Chem. 56, 358-364 (1930).

14. Tuck, D. G. Gallium and indium dihalides: a classic structural problem. Polyhedron 9, 377-386 (1990).

15. Baker, R. J. \& Jones, C. 'GaI': a versatile reagent for the synthetic chemist. Dalton Trans. 1341-1348 (2005).

16. Malbrecht, B. J., Dube, J. W., Willans, M. J. \& Ragogna, P. J. Addressing the chemical sorcery of 'GaI': benefits of solid-state analysis aiding in the synthesis of $\mathrm{P} \rightarrow \mathrm{Ga}$ coordination compounds. Inorg. Chem. 53, 9644-9656 (2014).

17. Schmidbaur, H. Arene complexes of univalent gallium, indium, and thallium. Angew. Chem. Int. Ed. Engl. 24, 893-904 (1985).

18. Schenk, C., Köppe, R., Schnöckel, H. \& Schnepf, A. A convenient synthesis of cyclopentadienylgallium - the awakening of a sleeping beauty in organometallic chemistry. Eur. J. Inorg. Chem. 2011, 3681-3685 (2011).

19. Asay, M., Jones, C. \& Driess, M. N-Heterocyclic carbene analogues with lowvalent group 13 and group 14 elements: syntheses, structures, and reactivities of a new generation of multitalented ligands. Chem. Rev 111, 354-396 (2011).

20. Dange, D., Choong, S. L., Schenk, C., Stasch, A. \& Jones, C. Synthesis and characterisation of anionic and neutral gallium(I) N-heterocyclic carbene analogues. Dalton Trans. 41, 9304-9315 (2012).

21. Linti, G. \& Schnöckel, H. Low valent aluminum and gallium compoundsstructural variety and coordination modes to transition metal fragments. Coord. Chem. Rev. 206-207, 285-319 (2000).

22. Pardoe, J. A. J. \& Downs, A. J. Development of the chemistry of indium in formal oxidation states lower than +3. Chem. Rev. 107, 2-45 (2007).

23. Fitz, H. \& Müller, B. G. $\mathrm{InBF}_{4}$, das erste komplexe Fluorid mit Indium(I). Z. Anorg. Allg. Chem. 623, 579-582 (1997).

24. Macdonald, C. L. B., Corrente, A. M., Andrews, C. G., Taylor, A. \& Ellis, B. D. Indium(I) trifluoromethanesulfonate and other soluble salts for univalent indium chemistry. Chem. Commun. 250-251 (2004).

25. Mazej, Z. Indium(I) hexafluoropnictates $\left(\mathrm{InPnF}_{6} ; \mathrm{Pn}=\mathrm{P}, \mathrm{As}, \mathrm{Sb}\right)$. Eur. J. Inorg. Chem. 2005, 3983-3987 (2005).

26. Welsch, S., Bodensteiner, M., Dušek, M., Sierka, M. \& Scheer, M. A novel soluble $\mathrm{In}^{\mathrm{I}}$ precursor for $\mathrm{P}_{n}$ ligand coordination chemistry. Chem. Eur. J. 16, 13041-13045 (2010).

27. Schneider, U. \& Kobayashi, S. Low-oxidation state indium-catalyzed C-C Bond formation. Acc. Chem. Res. 45, 1331-1344 (2012).

28. Slattery, J. M., Higelin, A., Bayer, T. \& Krossing, I. A simple route to univalent gallium salts of weakly coordinating anions. Angew. Chem. Int. Ed. 49, 3228-3231 (2010).

29. Higelin, A., Sachs, U., Keller, S. \& Krossing, I. Univalent gallium and indium phosphane complexes: from pyramidal $\mathrm{M}\left(\mathrm{PPh}_{3}\right)_{3}^{+}$to carbene-analogous bent $\mathrm{M}\left(\mathrm{P}_{\mathrm{Bu}}\right)_{2}^{+}(\mathrm{M}=\mathrm{Ga}, \mathrm{In})$ Complexes. Chem. Eur. J. 18, 10029-10034 (2012).

30. Higelin, A., Haber, C., Meier, S. \& Krossing, I. Isolated cationic crown ether complexes of gallium(I) and indium(I). Dalton Trans. 41, 12011-12015 (2012).

31. Higelin, A., Keller, S., Göhringer, C., Jones, C. \& Krossing, I. Unusual Tilted carbene coordination in carbene complexes of gallium(I) and indium(I). Angew. Chem. Int. Ed. 52, 4941-4944 (2013).

32. Lichtenthaler, M. R. et al. $\sigma$ - or $\pi$-coordination? Complexes of univalent gallium salts with aromatic nitrogen bases. Eur. J. Inorg. Chem. 2014, 4335-4341 (2014).

33. Lichtenthaler, M. R. et al. Univalent gallium salts of weakly coordinating anions: effective initiators/catalysts for the synthesis of highly reactive polyisobutylene. Organometallics 32, 6725-6735 (2013). 
34. Lichtenthaler, M. R. et al. Univalent gallium complexes of simple and ansaArene ligands: effects on the polymerization of isobutylene. Chem. Eur. J 21, 157-165 (2015).

35. Jones, C. Bulky Guanidinates for the stabilization of low oxidation state metallacycles. Coord. Chem. Rev. 254, 1273-1289 (2010).

36. Baker, R. J., Farley, R. D., Jones, C., Kloth, M. \& Murphy, D. M. The reactivity of diazabutadienes toward low oxidation state Group 13 iodides and the synthesis of a new gallium(I) carbene analogue. J. Chem. Soc., Dalton Trans. 3844-3850 (2002).

37. Tsai, Y.-C. The chemistry of univalent metal $\beta$-diketiminates. Coord. Chem. Rev. 256, 722-758 (2012)

38. Reger, D. L. Poly(pyrazolyl)borate complexes of gallium and indium. Coord. Chem. Rev. 147, 571-595 (1996).

39. Jurca, T., Lummiss, J., Burchell, T. J., Gorelsky, S. I. \& Richeson, D. S. Capturing $\mathrm{In}^{+}$monomers in a neutral weakly coordinating environment. J. Am. Chem. Soc. 131, 4608-4609 (2009).

40. Baker, R. J., Jones, C., Kloth, M. \& Mills, D. P. The reactivity of gallium(I) and indium(I) halides towards bipyridines, terpyridines, imino-substituted pyridines and bis(imino)acenaphthenes. New J. Chem. 28, 207-213 (2004).

41. Jurca, T. et al. Disproportionation and radical formation in the coordination of 'GaI' with bis(imino)pyridines. Dalton Trans. 39, 1266-1272 (2010).

42. Bondi, A. van der Waals volumes and Radii. J. Phys. Chem. 68, 441-451 (1964).

43. Mantina, M., Chamberlin, A. C., Valero, R., Cramer, C. J. \& Truhlar, D. G. Consistent van der Waals Radii for the whole main group. J. Phys. Chem. A 113, 5806-5812 (2009).

44. Baker, R. J., Bettentrup, H. \& Jones, C. The reactivity of primary and secondary amines, secondary phosphanes and N-heterocyclic carbenes towards Group-13 metal(I) halides. Eur. J. Inorg. Chem. 2003, 2446-2451 (2003).

45. Protchenko, A. V. et al. Stable $\mathrm{GaX}_{2}, \mathrm{InX}_{2}$ and $\mathrm{TlX}_{2}$ radicals. Nat. Chem 6, 315-319 (2014).

46. Cloke, F. G. N., Hanson, G. R., Henderson, M. J., Hitchcock, P. B. \& Raston, C. L. Synthesis and $\mathrm{X}$-ray crystal structure of the first homoleptic main group diazadiene complex, bis(1,4-di-t-butyl-1,4-diazabuta-1,3-diene) gallium. J. Chem. Soc., Chem. Commun. 1002-1003 (1989).

47. Kaim, W. \& Matheis, W. Bis(1,4-di-tert-butyl-1,4-diazabutadiene)gallium is not a gallium(II) compound. J. Chem. Soc., Chem. Commun. 597-598 (1991).

48. Baker, R. J. et al. An EPR and ENDOR Investigation of a Series of Diazabutadiene-Group 13 Complexes. Chem. Eur. J. 11, 2972-2982 (2005).

49. Tuononen, H. M. \& Armstrong, A. F. Theoretical investigation of paramagnetic diazabutadiene gallium(III) - pnictogen complexes: insights into the interpretation and simulation of electron paramagnetic resonance spectra. Inorg. Chem. 44, 8277-8284 (2005).

50. Tuononen, H. M. \& Armstrong, A. F. Theoretical investigation of paramagnetic group 13 diazabutadiene radicals: insights into the prediction and interpretation of EPR spectroscopy parameters. Dalton Trans. 1885-1894 (2006).

51. Záliš, S. et al. Origin of electronic absorption spectra of MLCT-excited and oneelectron reduced 2,2'-bipyridine and 1,10-phenanthroline complexes. Inorg. Chim. Acta 374, 578-585 (2011).

52. Gore-Randall, E., Irwin, M., Denning, M. S. \& Goicoechea, J. M. synthesis and characterization of alkali-metal salts of $2,2^{\prime}$ - and 2,4'-bipyridyl radicals and dianions. Inorg. Chem. 48, 8304-8316 (2009).

53. Wang, M., Weyhermueller, T., England, J. \& Wieghardt, K. Molecular and Electronic structures of six-coordinate 'low-valent' $\left[\mathrm{M}\left({ }^{\mathrm{Me}} \mathrm{bpy}\right)_{3}\right]^{0}(\mathrm{M}=\mathrm{Ti}, \mathrm{V}$, $\mathrm{Cr}, \mathrm{Mo})$ and $\left[\mathrm{M}(\mathrm{tpy})_{2}\right]^{0}(\mathrm{M}=\mathrm{Ti}, \mathrm{V}, \mathrm{Cr})$, and seven-coordinate $\left[\mathrm{MoF}\left(\mathrm{Me}^{\mathrm{bpy}}\right)_{3}\right]\left(\mathrm{PF}_{6}\right)$ and $\left[\mathrm{MX}\left(\mathrm{tpy}_{2}\right)_{2}\right]\left(\mathrm{PF}_{6}\right)(\mathrm{M}=\mathrm{Mo}, \mathrm{X}=\mathrm{Cl}$ and $\mathrm{M}=\mathrm{W}$, $\mathrm{X}=\mathrm{F})$. Inorg. Chem. 52, 12763-12776 (2013).

54. Li, X.-W., Pennington, W. T. \& Robinson, G. H. Metallic system with aromatic character. synthesis and molecular structure of $\mathrm{Na}_{2}\left[\left[\left(2,4,6-\mathrm{Me}_{3} \mathrm{C}_{6} \mathrm{H}_{2}\right)_{2} \mathrm{C}_{6} \mathrm{H}_{3}\right]\right.$ $\mathrm{Ga}_{3}$ the first cyclogallane. J. Am. Chem. Soc. 117, 7578-7579 (1995).

55. Wiberg, N. et al. On the Gallanyls $\mathrm{R}_{3}^{*} \mathrm{Ga}_{2} \cdot$ and $\mathrm{R}_{4}^{*} \mathrm{Ga}_{3}$ As Well As Gallanides $\mathrm{R}_{3}^{\star} \mathrm{Ga}_{2}^{-}$and $\mathrm{R}_{4} \mathrm{Ga}_{3}^{-}\left(\mathrm{R}^{\star}=\mathrm{Si} t \mathrm{Bu}_{3}\right)$-Syntheses, Characterization, Structures. Eur. J. Inorg. Chem. 2001, 1719-1727 (2001).

56. Litters, S., Kaifer, E., Enders, M. \& Himmel, H.-J. A boron-boron coupling reaction between two ethyl cation analogues. Nat. Chem 5, 1029-1034 (2013).

57. Mingos, D. M. P. General theory for cluster and ring compounds of the main group and transition elements. Nat. Phys. Sci 236, 99-102 (1972).

58. Krossing, I. The facile preparation of weakly coordinating anions: structure and characterisation of silver polyfluoroalkoxyaluminates $\operatorname{AgAl}\left(\mathrm{OR}^{\mathrm{F}}\right)_{4}$, calculation of the alkoxide ion affinity. Chem. Eur. J 7, 490-502 (2001).

59. Power, P. P. in Group 13 Chemistry I Vol. 103 Structure and Bonding. Ch. 2 57-84 (Springer Berlin Heidelberg, 2002).

60. Driess, M. \& Grützmacher, H. Main group element analogues of carbenes, olefins, and small rings. Angew. Chem. Int. Ed. Engl. 35, 828-856 (1996)

61. Kaim, W. Manifestations of noninnocent ligand behavior. Inorg. Chem. 50, 9752-9765 (2011)
62. Sundermann, A., Reiher, M. \& Schoeller, W. W. Isoelectronic arduengo-type carbene analogues with the group IIIa elements boron, aluminum, gallium, and indium. Eur. J. Inorg. Chem. 1998, 305-310 (1998).

63. Allan, C. J., Cooper, B. F. T., Cowley, H. J., Rawson, J. M. \& Macdonald, C. L. B. Non-innocent ligand effects on low-oxidation-state indium complexes. Chem. Eur. J. 19, 14470-14483 (2013).

64. Hellmann, K. W. et al. metal-ligand versus metal-metal redox chemistry: thallium(I)-Induced synthesis of 4,9-diaminoperylenequinone-3,10-diimine derivatives. Angew. Chem. Int. Ed. 37, 1948-1952 (1998).

65. Klamt, A. \& Schuurmann, G. COSMO: a new approach to dielectric screening in solvents with explicit expressions for the screening energy and its gradient. J. Chem. Soc., Perkin Trans. 2, 799-805 (1993).

66. Jenkins, H. D. B., Roobottom, H. K., Passmore, J. \& Glasser, L. Relationships among ionic lattice energies, molecular (formula unit) volumes, and thermochemical radii. Inorg. Chem. 38, 3609-3620 (1999).

67. Brack, M. The physics of simple metal clusters: self-consistent jellium model and semiclassical approaches. Rev. Mod. Phys. 65, 677-732 (1993).

68. Morton, J. R. \& Preston, K. F. Atomic parameters for paramagnetic resonance data. J. Magn. Reson. 30, 577-582 (1978).

69. Weil, J. A. \& Bolton, J. R. in Electron Paramagnetic Resonance 583John Wiley \& Sons, Inc., 2006).

70. Dedieu, A. \& Hoffmann, R. Platinum(0)-platinum(0) dimers. Bonding relationships in a d10-d10 system. J. Am. Chem. Soc. 100, 2074-2079 (1978).

\section{Acknowledgements}

This work was supported by the Albert-Ludwigs-Universität Freiburg and by the DFG in the Normalverfahren. We would like to thank Fadime Bitgül and Dr Harald Scherer for the measurement of the NMR spectra, B.Sc. Boumahdi Benkmil for his support regarding single-crystal X-ray analysis, Dr Michael Schwarz and Prof. Dr Caroline Röhr for their support during the attempted preparation of single-crystalline EPR samples. This work is dedicated to the occasion of the 60th birthday of Prof. Dr. Manfred Scheer in Regensburg.

\section{Author contributions}

M.R.L. initiated and coordinated the project, conducted the synthesis of 4, 5, 6, 7 and 8 reproduced the synthesis of $\mathbf{3}$, characterized the obtained compounds, performed the DFT calculations and wrote the manuscript with assistance of I.K.; during his apprenticeship and under the supervision of M.R.L., F.S. performed the synthesis of $\mathbf{1}$ and 3; D.K. contributed valuable support in solving and refining the single-crystal structures; L.H., E.S. and S.W. conducted the EPR measurements of 3, contributed the simulated spectra and drafted the EPR-related part of the manuscript. S.W. also revised the completed manuscript; During his bachelor thesis and under the supervision of M.R.L., J.H. performed the synthesis of 2; D.H. provided important advice regarding the DFT calculations and revised the manuscript; I.K. directed the project, conceived the central ideas concerning the formation of the reported compounds and drafted parts of the manuscript.

\section{Additional information}

Accession codes: The X-ray crystallographic coordinates for structures reported in this study have been deposited at the Cambridge Crystallographic Data Centre (CCDC), under deposition numbers CCDC 1032681 (3), CCDC 1032680 (4), CCDC 1033040 (5), CCDC 1032732 (6), CCDC 1034231 (7) and CCDC 1034089 (8). These data can be obtained free of charge from The Cambridge Crystallographic Data Centre via www.ccdc.cam.ac.uk/data_request/cif.

Supplementary Information accompanies this paper at http://www.nature.com/ naturecommunications

Competing financial interests: The authors declare no competing financial interests.

Reprints and permission information is available online at http://npg.nature.com/ reprintsandpermissions/

How to cite this article: Lichtenthaler, M. R. et al. Cationic cluster formation versus disproportionation of low-valent indium and gallium complexes of 2,2'-bipyridine. Nat. Commun. 6:8288 doi: 10.1038/ncomms9288 (2015).

This work is licensed under a Creative Commons Attribution 4.0 International License. The images or other third party material in this article are included in the article's Creative Commons license, unless indicated otherwise in the credit line; if the material is not included under the Creative Commons license, users will need to obtain permission from the license holder to reproduce the material. To view a copy of this license, visit http://creativecommons.org/licenses/by/4.0/ 